\title{
ELMOD1 Stimulates ARF6-GTP Hydrolysis to Stabilize Apical Structures in Developing Vestibular Hair Cells
}

\author{
Jocelyn F. Krey, ${ }^{1}$ Rachel A. Dumont, ${ }^{1}$ Philip A. Wilmarth, ${ }^{2}$ Larry L. David, ${ }^{2}$ Kenneth R. Johnson, ${ }^{3}$ \\ and $\triangleright^{\circ}$ Peter G. Barr-Gillespie ${ }^{1}$ \\ ${ }^{1}$ Oregon Hearing Research Center and Vollum Institute, ${ }^{2}$ Department of Biochemistry and Molecular Biology, Oregon Health and Science University, \\ Portland, Oregon 97239, and ${ }^{3}$ The Jackson Laboratory, Bar Harbor, Maine 04609
}

Sensory hair cells require control of physical properties of their apical plasma membranes for normal development and function. Members of the ADP-ribosylation factor (ARF) small GTPase family regulate membrane trafficking and cytoskeletal assembly in many cells. We identified ELMO domain-containing protein 1 (ELMOD1), a guanine nucleoside triphosphatase activating protein (GAP) for ARF6, as the most highly enriched ARF regulator in hair cells. To characterize ELMOD1 control of trafficking, we analyzed mice of both sexes from a strain lacking functional ELMOD1 [roundabout $(r d a)$ ]. In $r d a / r d a$ mice, cuticular plates of utricle hair cells initially formed normally, then degenerated after postnatal day 5 ; large numbers of vesicles invaded the compromised cuticular plate. Hair bundles initially developed normally, but the cell's apical membrane lifted away from the cuticular plate, and stereocilia elongated and fused. Membrane trafficking in type I hair cells, measured by FM1-43 dye labeling, was altered in $r d a / r d a$ mice. Consistent with the proposed GAP role for ELMOD1, the ARF6 GTP/GDP ratio was significantly elevated in $r d a / r d a$ utricles compared with controls, and the level of ARF6-GTP was correlated with the severity of the rda/rda phenotype. These results suggest that conversion of ARF6 to its GDP-bound form is necessary for final stabilization of the hair bundle.

Key words: ARF; hair cells; stereocilia

Significance Statement

Assembly of the mechanically sensitive hair bundle of sensory hair cells requires growth and reorganization of apical actin and membrane structures. Hair bundles and apical membranes in mice with mutations in the Elmod1 gene degenerate after formation, suggesting that the ELMOD1 protein stabilizes these structures. We show that ELMOD1 is a GTPase-activating protein in hair cells for the small GTP-binding protein ARF6, known to participate in actin assembly and membrane trafficking. We propose that conversion of ARF6 into the GDP-bound form in the apical domain of hair cells is essential for stabilizing apical actin structures like the hair bundle and ensuring that the apical membrane forms appropriately around the stereocilia.

\section{Introduction}

A hair cell in the inner ear transduces auditory and vestibular stimuli with its hair bundle, a mechanically sensitive cluster of

\footnotetext{
Received Sept. 11, 2017; revised Nov. 21, 2017; accepted Nov. 30, 2017

Author contributions: J.F.K., L.L.D., K.R.J., and P.G.B.-G. designed research; J.F.K. and R.A.D. performed research; J.F.K., P.A.W., L.L.D., and P.G.B.-G. analyzed data; J.F.K. and P.G.B.-G. wrote the paper.

This work was supported by NIH Grants R01 DC002368, R01 DC011034, and P30 DC005983 to P.G.B.-G.; the following core facilities: mass spectrometry from the OHSU Proteomics Shared Resource (partial support from NIH core Grant P30 EY010572), confocal microscopy from the OHSU Advanced Light Microscopy Core at The Jungers Center (P30 NS061800 provided support for imaging); and hybridoma cells for JLA20 (deposited by J. J.-C. Lin) and DSHB-GFP-4C9 were obtained from the Developmental Studies Hybridoma Bank, created by the NICHD of the NIH and maintained at The University of lowa, Department of Biology, lowa City, IA. We thank David Corey for sharing transcriptomics data before publication.

The authors declare no competing financial interests.

Correspondence should be addressed to Dr. Peter G. Barr-Gillespie, Oregon Hearing Research Center, L335A Oregon Health and Science University, 3181 Southwest Sam Jackson Park Road, Portland, OR 97239. E-mail: gillespp@ohsu.edu.
}

actin-rich stereocilia that emanate from the cell's apex (Gillespie and Müller, 2009). Apical membranes play a unique, fundamental role in inner-ear function and, accordingly, apical and basolateral membranes of hair cells differ in their phospholipid and membrane-protein content (Zhao et al., 2012). Hair cells have been reported to recycle their apical membranes at a rate of $>1$ $\mu \mathrm{m}^{2} / \mathrm{s}$, leading to a complete turnover of the apical membrane in $<1$ min (Griesinger et al., 2002, 2004). Moreover, membrane tension likely regulates stereocilia length (Prost et al., 2007; Manor and Kachar, 2008) and mechanotransduction (Powers et al., 2012, 2014; Peng et al., 2016). Control of the balance between exocytosis and endocytosis is critical, as a slight mismatch can lead to morphological abnormalities like membrane blebbing (Shi et al., 2005). 
The ADP-ribosylation factor (ARF) family of small GTPases, which includes the classic ARFs and the ARF-like (ARL) proteins, regulates membrane trafficking in most cell types (D'SouzaSchorey and Chavrier, 2006). ARF6 in particular regulates endosomal membrane traffic and apical membrane structure, through both clathrin-mediated and clathrin-independent apical endocytosis (Doherty and McMahon, 2009). ARF6 also regulates cellular actin through its interactions with RHO family members like RAC1 and CDC42 (Franco et al., 1999; Radhakrishna et al., 1999; Hyman et al., 2006; Klein et al., 2006; Osmani et al., 2010). Like other small GTPases, the ARFs are activated by guanine-nucleotide exchange factors (GEFs) and inhibited by GTPase-activating proteins (GAPs). The ELMO domain-containing protein family (ELMODs) consists of six paralogs in mammals, two of which (ELMOD1 and ELMOD2) have been shown to be ARF-family GAPs (East et al., 2012; Ivanova et al., 2014). ELMOD1 had its greatest GAP activity toward ARF6, whereas ELMOD2 was a GAP for ARL2 (Ivanova et al., 2014).

Mutations in ELMOD1 lead to deafness and vestibular dysfunction in mice (Johnson et al., 2012). The roundabout ( $r d a$ ) allele has a large deletion in the first half of the Elmod1 gene, which results in loss of ELMOD1 protein expression (Johnson et al., 2012). Beginning after postnatal day (P)7, mice homozygous for the $r d a$ mutation ( $r d a / r d a$ ) develop morphological abnormalities in cochlear hair cells, including fusion and elongation of inner hair cell stereocilia and degradation of outer hair cell stereocilia (Johnson et al., 2012). Little is known of the consequences of the $r d a$ mutation on vestibular hair cells, however, although circling exhibited by the homozygous mutant mice suggests a lack of vestibular function. ELMOD1 is also expressed within the brain, and has been detected in cerebellar Purkinje cells and granule cells and pyramidal neurons within the hippocampus (Johnson et al., 2012). Interestingly, a mutation in Elmod3 was recently linked to deafness in humans as well (Jaworek et al., 2013), confirming the significance of this protein family for inner-ear function.

To examine the role of ELMOD1 in mouse vestibular hair cells, we determined by immunoblotting that it is developmentally regulated, peaking near the end of vestibular hair cell development. Hair cells initially developed normally in $r d a / r d a$ mice, but by P5, defects in the cuticular plate were observed, followed by stereocilia degeneration. Like with mouse mutations in Myo6, Ptprq, and $R d x$, apical membranes lifted up and the stereocilia actin cores elongated and fused, leaving in the most extreme cases a single giant stereocilium. We used $r d a / r d a$ mice to demonstrate the GAP activity of ELMOD1 toward ARF6, suggesting that the consequences of the Elmod1 mutation were due to elevated ARF6GTP levels. We propose that ARF6 must be converted to the GDP form at apical surfaces to permit stabilization of the hair bundle's actin and membrane structures.

\section{Materials and Methods}

Nomenclature. Per convention (http://www.informatics.jax.org/mgihome/ nomen/gene.shtml), all protein names use the official gene symbol (http://www.genenames.org) with all caps and no italics.

Mice. $r d a$ mice on a C57BL/6J background were obtained from The Jackson Laboratory. To obtain mice heterozygous and homozygous for the $r d a$ mutation, $+/ r d a$ females were crossed to $r d a / r d a$ males. These crosses allowed us to generate equal numbers of knock-out mice and heterozygote controls, which was especially important for proteomics experiments. C57BL/6 mice were used as wild-type controls (referred to as B6).

Experimental design and statistical analyses. Because $+/ r d a$ mice have normal auditory and vestibular function (Johnson et al., 2012), only comparisons of $+/ r d a$ to $r d a / r d a$, which have the same genetic back- ground, were functionally relevant. Because of the different genetic backgrounds, B6 comparisons to $+/ r d a$ and $r d a / r d a$ are of less relevance for determining mechanisms. The Student's $t$ test was used for all pairwise comparisons (two-sided, two-sample, equal variance). Data distribution was assumed to be normal but this was not formally tested.

Mass spectrometry of TMT-labeled utricle extracts. Utricles were dissected from $+/ r d a$ and $r d a / r d a$ mice at P12. Four biological replicates were prepared for each genotype with four to six utricles per replicate. Lysates were prepared using the eFASP method (Erde et al., 2014). Briefly, lysis buffer ( $4 \%$ SDS, $0.2 \%$ deoxycholic acid) at $15 \mu$ l per utricle was added to each tube and samples were vortexed, heated to $90^{\circ} \mathrm{C}$ for 10 $\mathrm{min}$, and bath sonicated for $5 \mathrm{~min}$. Protein concentration of each lysate was measured using the Micro BCA Protein Assay Kit (ThermoFisher Scientific). Lysates were divided into $2 \mu \mathrm{g}$ aliquots. Samples were then digested as described previously (Erde et al., 2014), with triethylammonium bicarbonate (TEAB) replacing the ammonium bicarbonate in all solutions.

Peptides were each reconstituted in $25 \mu$ l of $100 \mathrm{~mm}$ TEAB and labeled with 10-plex Tandem Mass Tag (TMT) reagents from ThermoFisher Scientific. TMT reagents $(0.8 \mathrm{~g})$ were each dissolved in $52 \mu \mathrm{l}$ anhydrous acetonitrile. Each sample, containing $2 \mu \mathrm{g}$ of peptide in $25 \mu \mathrm{l}$ volume of TEAB buffer, was combined with $12 \mu \mathrm{l}$ of its respective TMT reagent and incubated for $1 \mathrm{~h}$ at room temperature. Two microliters of each reaction mixture was then added, and the mixture was incubated at room temperature for $1 \mathrm{~h} ; 2 \mu \mathrm{l}$ of $5 \%$ hydroxylamine was added, and the combined sample was incubated for a further $15 \mathrm{~min}$. The mixture was dried down and dissolved in 5\% formic acid. A $2 \mu \mathrm{g}$ aliquot of labeled peptide was analyzed by a single $2 \mathrm{~h}$ LC-MS/MS method using an Orbitrap Fusion as described below; this run was performed to normalize the total reporter ion intensity of each multiplexed sample and check labeling efficiency. The remaining samples were quenched by addition of $2 \mu$ l of $5 \%$ hydroxylamine as above, combined in a 1:1:1:1:1:1:1:1:1:1 ratio based on total reporter ion intensities determined during the normalization run, and dried down in preparation for 2D-LC-MS/MS analysis.

Multiplexed TMT-labeled samples were reconstituted in 5\% formic acid and separated by two-dimensional reverse-phase liquid chromatography using a Dionex NCS-3500RS UltiMate RSLCnano UPLC system. A $20 \mu \mathrm{l} \mathrm{sample}(10.4 \mu \mathrm{g})$ was injected onto a NanoEase $5 \mu \mathrm{m}$ XBridge BEH130 C18 $300 \mu \mathrm{m} \times 50 \mathrm{~mm}$ column (Waters) at $3 \mu \mathrm{l} / \mathrm{min}$ in a mobile phase containing $10 \mathrm{~mm}$ ammonium formate at $\mathrm{pH}$ 9. Peptides were eluted by sequential injection of $20 \mu \mathrm{l}$ volumes of $14,20,24,28,35$, and $90 \%$ acetonitrile in $10 \mathrm{~mm}$ ammonium format, $\mathrm{pH} 9$, at $3 \mu \mathrm{l} / \mathrm{min}$ flow rate. Eluted peptides were diluted with mobile phase containing $0.1 \%$ formic acid at $24 \mu \mathrm{l} / \mathrm{min}$ flow rate and delivered to an Acclaim PepMap (ThermoFisher Scientific) $100 \mu \mathrm{m} \times 2 \mathrm{~cm}$ NanoViper C18 (5 $\mu \mathrm{m})$ trap on a switching valve. After $10 \mathrm{~min}$ of loading, the trap column was switched in-line to a PepMap RSLC C18, $2 \mu \mathrm{m}, 75 \mu \mathrm{m} \times 25 \mathrm{~cm}$ EasySpray column (ThermoFisher Scientific). Peptides were then separated at low $\mathrm{pH}$ in the second dimension using a 7.5-30\% acetonitrile gradient over $90 \mathrm{~min}$ in mobile phase containing $0.1 \%$ formic acid at $300 \mathrm{nl} / \mathrm{min}$ flow rate. Each second dimension LC run required $2 \mathrm{~h}$ for separation and reequilibration, so each 2D LC-MS/MS method required $12 \mathrm{~h}$ for completion. Tandem mass spectrometry data were collected using an Orbitrap Fusion Tribrid instrument configured with an EasySpray NanoSource (ThermoFisher Scientific). Survey scans were performed in the Orbitrap mass analyzer (resolution $=120,000$ ), and data-dependent MS2 scans were performed in the linear ion trap using collision-induced dissociation (normalized collision energy $=35$ ) following isolation with the instrument's quadrupole. Reporter ion detection was performed in the Orbitrap mass analyzer (resolution $=60,000$ ) using MS3 scans following synchronous precursor isolation of the top 10 ions in the linear ion trap, and higher-energy collisional dissociation in the ion-routing multipole (normalized collision energy $=65$ ).

Confident peptide identifications and reporter ion peak heights were obtained using Proteome Discoverer v1.4 (ThermoFisher Scientific). SEQUEST search parameters were as follows: parent ion tolerance of 1.25 $\mathrm{Da}$, fragment ion tolerance of $1.0 \mathrm{Da}$, tryptic cleavage with no more than two missed cleavages, variable oxidation of Met, and static modifications for alkylation and TMT reagents. A custom protein database with com- 

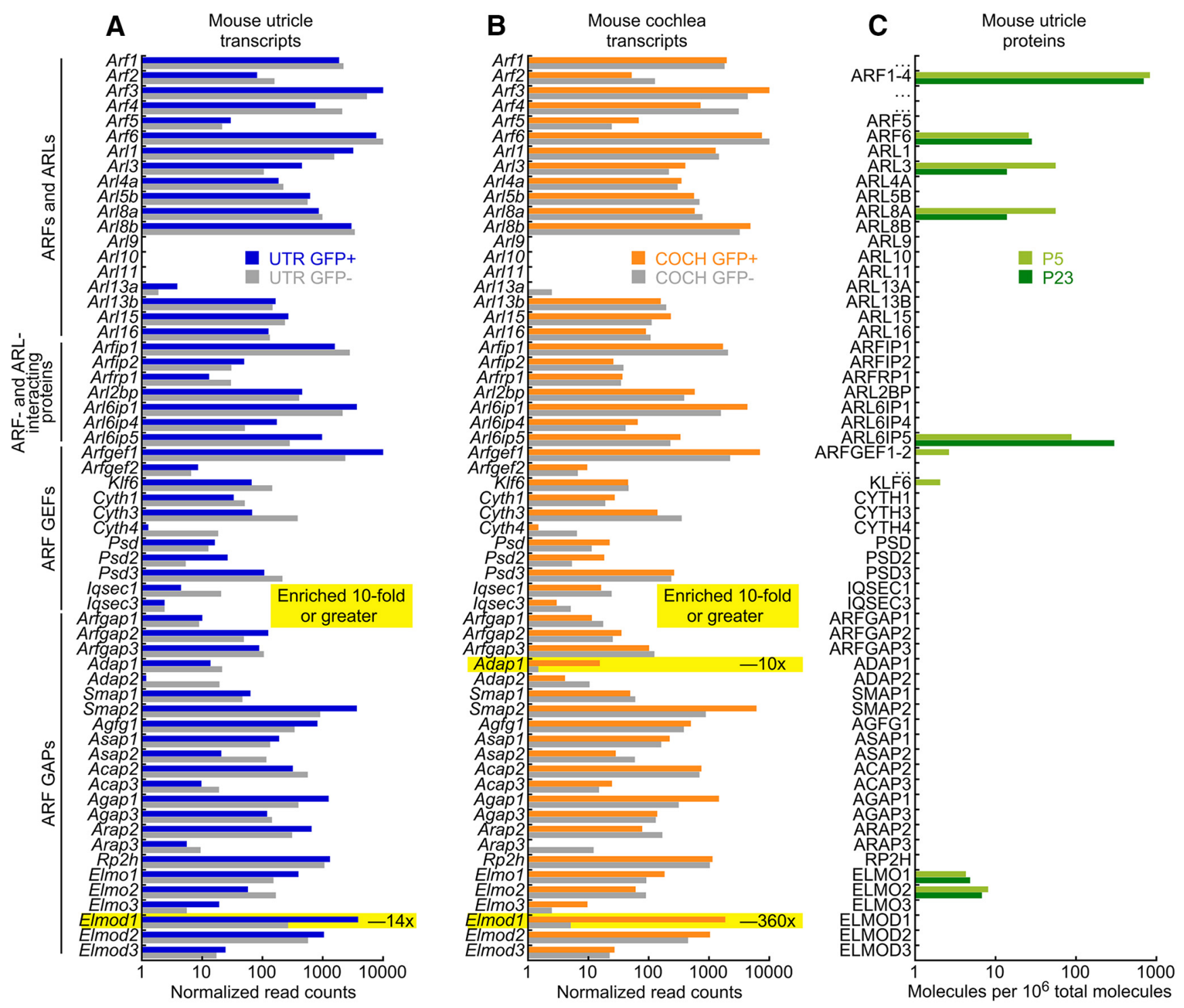

Figure 1. ARF and ARF modulator transcript analysis in hair cells. $A$, Transcript levels in sorted hair cells (GFP+) and other inner ear cells (GFP-) from mouse utricle; data from Scheffer et al. (2015). Levels are averaged over measurements from developmental ages E16 -P16.B, Cochlear transcript levels. Levels are averaged over E16-P7. C, ARF and ARF-modulator proteins detected by mass spectrometry in P5 and P23 hair bundles and utricle; data from Krey et al. (2015). Because of shared peptides, ARFs $1-4$ and ARFGEFs 1 and 2 could not be unambiguously quantified individually and thus were combined.

plete coverage and minimal peptide redundancy was used. Protein database details and description of the quantitative analysis are provided in ProteomeXchange submission below; TMT data processing and statistical testing has been previously described (Plubell et al., 2017).

The mass spectrometry proteomics data have been deposited to the ProteomeXchange Consortium via the PRIDE partner repository (Vizcaíno et al., 2016) with the dataset identifier PXD006164.

Immunoblotting. Hair bundles and utricles were isolated from C57BL/ $6 \mathrm{~J},+/ r d a$, and $r d a / r d a$ mice and then were subjected to SDS-PAGE and immunoblotting as described previously (Shin et al., 2013). Western blots were probed with a 1:1000 dilution of anti-ELMOD1 antibody (NBP1-85094, Novus Biologicals; RRID:AB_11005087), a 1:100 dilution of anti-ARF6 antibody (3A1; sc-7971, Santa Cruz Biotechnology; RRID: AB_2289810), or a 1:2000 dilution of anti-actin antibody (JLA20, Developmental Studies Hybridoma Bank; RRID:AB_528068).

Measurement of ARF6-GTP binding. To measure ARF-GTP levels, we used the ARF6 Pull-down Activation Assay Biochem Kit (Cytoskeleton, BK033-S), following the manufacturer's instructions with several modifications. Utricles were isolated from C57BL/6J, $+/ r d a$, and $r d a / r d a$ mice at P11-P12, and otolithic membranes were removed using an eyelash.
Four to eight organs were dissected at a time from each genotype and kept on ice during the dissection process. Utricles were transferred to a tube in a small amount of dissection solution; the tube was gently spun in a microcentrifuge and most of the solution was removed. Lysis buffer containing 1:100 Protease Inhibitor Cocktail (included in kit) was added to organs (10 $\mu$ l lysis buffer per utricle). Utricles were probe-sonicated with $3 \times 5 \mathrm{~s}$ pulses at $25 \%$ amplitude while on ice, then flash frozen in liquid nitrogen and stored at $-80^{\circ} \mathrm{C}$. Frozen samples were gently thawed on ice, and then spun at $4^{\circ} \mathrm{C}$ in a microcentrifuge at max speed for $2 \mathrm{~min}$. A small aliquot $(4-6 \mu \mathrm{l})$ of the solution was saved as total lysate sample, and the remaining solution was transferred to a new tube and brought up to a $100 \mu \mathrm{l}$ volume with additional lysis buffer. Lysates were mixed on a rotator for $1 \mathrm{~h}$ at $4^{\circ} \mathrm{C}$ with $10 \mu \mathrm{l}(10 \mu \mathrm{g})$ of GGA3 beads, and then spun down at $4500 \times g$ at $4^{\circ} \mathrm{C}$ for $2 \mathrm{~min}$. The supernatant was removed and beads were washed twice, each with $600 \mu \mathrm{l}$ of wash buffer followed by a spin at $4500 \times g$ at $4^{\circ} \mathrm{C}$ for $2 \mathrm{~min}$. The wash buffer was removed from beads and $10 \mu \mathrm{l}$ of $2 \times$ LDS sample buffer with reducing agent (ThermoFisher Scientific) was added to each tube. An equal amount of $2 \times$ LDS sample buffer was also added to the total lysates. Tubes were incubated for $2 \mathrm{~min}$ at $95^{\circ} \mathrm{C}$ and then samples were separated on a $1 \mathrm{~mm} \mathrm{12}$-well 

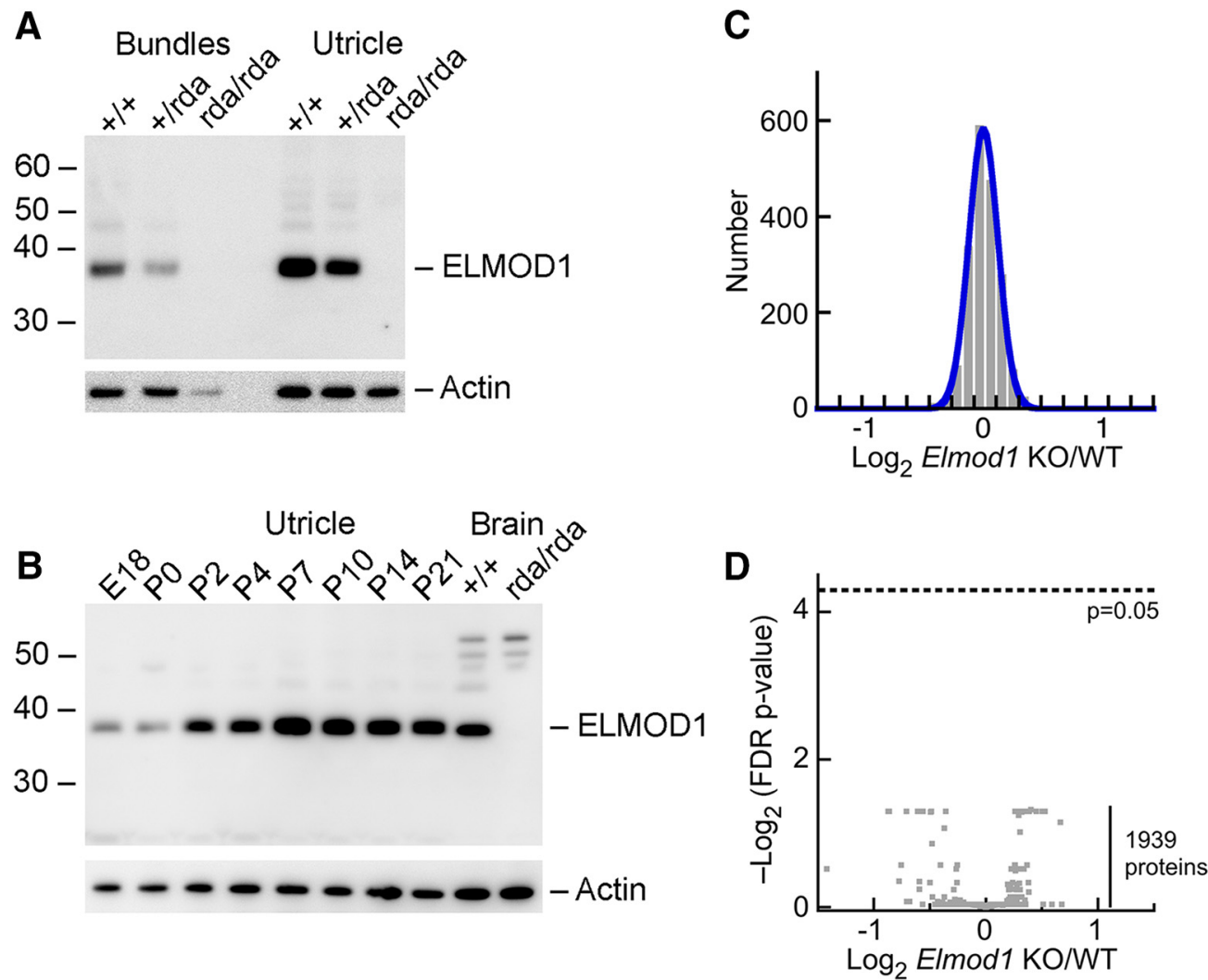

Figure 2. ELMOD1 protein analysis. $A$, Immunoblot detection of ELMOD1 in mouse hair bundles and whole utricles from wild-type, heterozygous $+/$ rda, and homozygous $r d a / r d a$ mice. Identical samples were analyzed for actin. B, Developmental time course of ELMOD1 expression in whole utricle. $C$, $\log _{2}$ ratio of expression for 1939 proteins detected in 4/4 rda/rda utricle samples and 4/4 $+/+$ samples. $\boldsymbol{D}$, Volcano plot comparing rda/rda to $+/+$ ratio ( $x$-axis) with FDR-adjusted $p$ value $(y$-axis). No proteins approach the $p=0.05$ significance level.

$12 \%$ Bis-Tris gel (Life Technologies) run with MES running buffer. Gels were transferred for $1 \mathrm{~h}$ at $22 \mathrm{~V}$ at $4^{\circ} \mathrm{C}$ onto $0.2 \mu \mathrm{m}$ PVDF membranes (Immobilon $\mathrm{P}^{\mathrm{SQ}}$, Millipore). Protein immunoblots were probed as described above using anti-ARF6 and anti-actin antibodies.

In utero electroporation. Elmod 1 was cloned from a mouse brain cDNA library and inserted into a GFP-C1 vector. Pregnant female mice (C57BL/ $6 \times \mathrm{CD} 1$ crosses) were anesthetized and up to eight embryos at E10.5-E12.5 were injected in the otocyst with $<200 \mathrm{nl}$ of the GFP-ELMOD1 construct. Surgical procedures were performed as described previously (Ebrahim et al., 2016).

Immunocytochemistry and imaging. Using 4\% formaldehyde in PBS, utricles were fixed for $4-12 \mathrm{~h}$ and cochleas were fixed for $0.5-1 \mathrm{~h}$. Organs were then rinsed in PBS, permeabilized for $10 \mathrm{~min}$ in $0.5 \%$ Triton X-100 in PBS, and blocked for $1-2 \mathrm{~h}$ in $2 \%$ bovine serum albumin and $5 \%$ normal goat serum in PBS. For immunolocalization of ARF6 and other membrane compartment markers, organs were permeabilized and blocked for $1 \mathrm{~h}$ in $5 \%$ normal goat serum and $0.2 \%$ saponin in PBS; this blocking solution was used in all subsequent antibody steps. Organs were incubated overnight at $4^{\circ} \mathrm{C}$ with primary antibodies diluted in blocking solution; a dilution of 1:250 was used for anti-ELMOD1 and 1:1000 for anti-acetylated tubulin (Sigma-Aldrich, T7451; RRID:AB_609894). For ARF6 and other membrane markers, the following dilutions were used: 1:100 anti-ARF6, 1:250-activated ARF6 (NewEast Biosciences, 26918; RRID:AB_2629397); 1:250 anti-clathrin heavy chain (X22, MA1-065, ThermoFisher Scientific; RRID:AB_2083179), 1:250 anti-EEA1 (3288, Cell Signaling Technology; RRID:AB_2096811), 1:250 anti-Rab11 (5589, Cell Signaling Technology; RRID:AB_10693925), 1:250 anti-Rab5 (3547, Cell Signaling Technology; RRID:AB_2300649), and 1:250 antiLAMP1 (H4A3, Developmental Studies Hybridoma Bank; RRID: AB_2296838). Organs were then rinsed $3 \times$ for 10 min each, followed by a 3-4 h incubation in blocking solution with 1:1000 AlexaFluor secondary antibodies and $0.4 \mathrm{U} / \mathrm{ml}$ AlexaFluor 488 Phalloidin (Invitrogen). Similarly, utricles from electroporated ears were fixed and stained as above using an anti-GFP (DSHB-GFP-4C9, Developmental Studies Hybridoma Bank; RRID:AB_2617422) primary antibody and TRITCphalloidin. Following secondary antibody incubation, organs were then rinsed $3 \times$ for 20 min each and mounted on slides in Vectashield (Vector Laboratories) using a single Secure-Seal spacer ( 8 wells, $0.12 \mathrm{~mm}$ deep; Invitrogen). Images were acquired on an Olympus Fluoview FV1000 laser scanning confocal microscope system and AF10-ASW 3.0 acquisition software, using a $60 \times 1.42$ NA Plan Apo objective with $3 \times$ zoom and $0.4 \mu \mathrm{m} z$-steps. ARF6 and ARG-GTP images were collected on a Zeiss LSM 710 using either a $63 \times 1.4$ NA Plan-Apochromat or $25 \times 0.8$ NA Plan-Neofluar objective. Fiji software was used to adjust intensities, generate reslice stacks, and prepare stack projections. To analyze ARF6 and ARF6-GTP levels, average $z$-projections centered around the cuticular plate were generated for two separate areas within each $25 \times$ stack. Regions-of-interest (ROIs) surrounding the cuticular plate (as visualized by phalloidin) were generated for $40-50$ cells per image, and mean intensities were measured in each channel using the multi-measure function within the ROI Manager tool in Fiji. To correct for global intensity differences between samples imaged on different days, measurements were corrected for background levels within each image and normalized to the total phalloidin average. To quantify changes in hair-cell structure during progression of the $r d a / r d a$ phenotype, we scored six different morphological phenotypes on a scale of 0 (identical to control), 1 (noticeably different from control), or 2 (very noticeable). The phenotypes scored were as follows: gaps in cuticular plate actin, protrusion of apical surface, movement of the bundle toward the fonticulus, decrease in bundle cross-sectional area, increase in the proportion of long stereocilia in a bundle, and fusion of stereocilia. For analysis of morphological changes, we analyzed a mixture of type I and type II hair cells. To analyze the correlation between ARF6-GTP level and phenotype, ROIs were generated around the cuticular plate region of 40 cells within each $63 \times$ stack and ARF6-GTP intensities were measured using Fiji; measurements from 

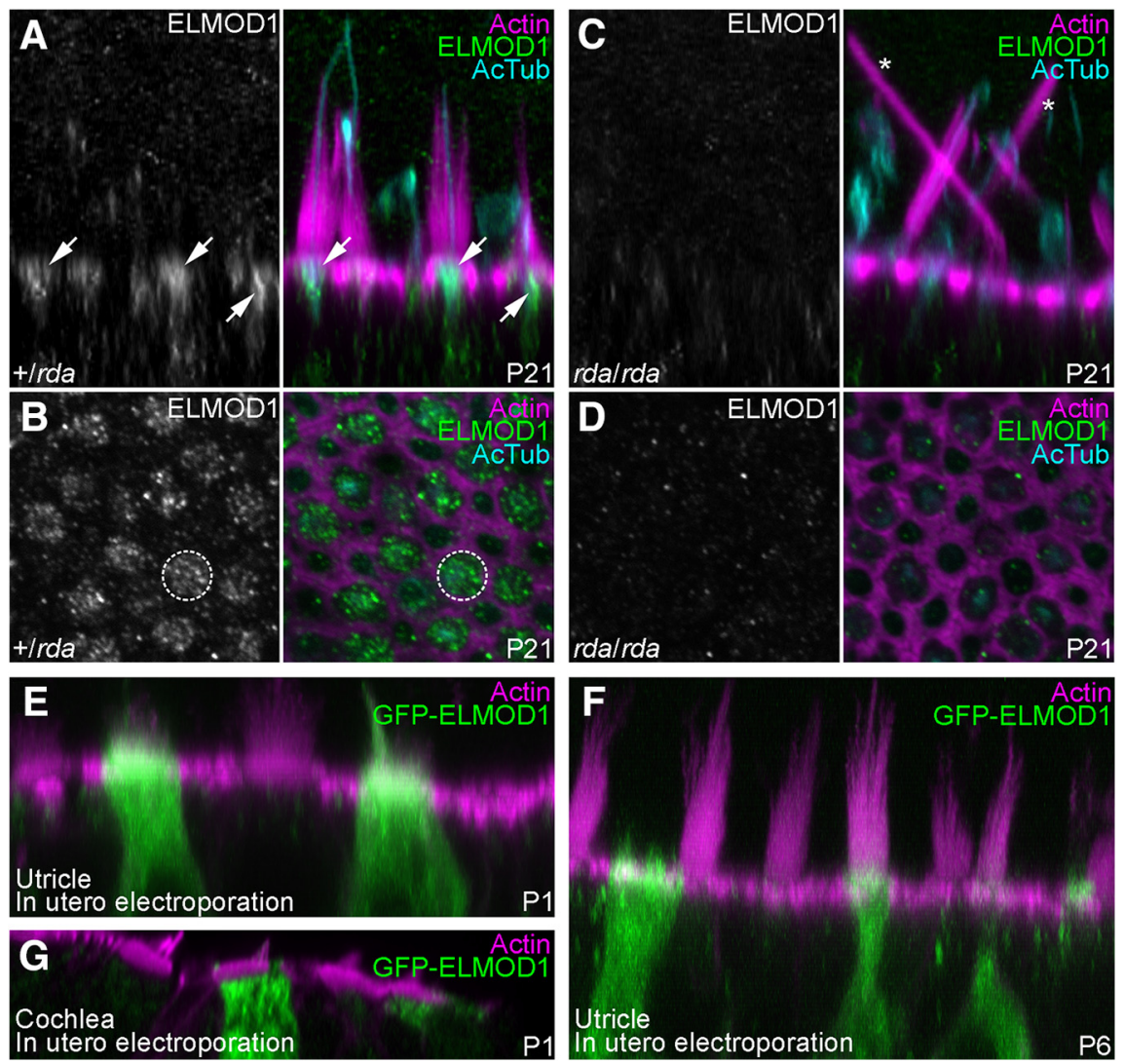

Figure 3. Localization of ELMOD1 in utricle hair cells. $\boldsymbol{A}-\boldsymbol{D}$, Confocal images of utricle hair cells from $\mathrm{P} 21+/ \mathrm{rda}(\boldsymbol{A}, \boldsymbol{B})$ or $r d a / r d a$ $(\boldsymbol{C}, \boldsymbol{D})$ mice. Images were $x$ - $z$ reslices $(\boldsymbol{A}, \boldsymbol{C})$ to show ELM0D1 distribution at the apical region of hair cells (arrows) or $x$ - $y$ confocal sections $(\boldsymbol{B}, \boldsymbol{D})$ to show ELMOD1 at the cuticular plate level (dashed circle). No ELMOD1 signal is seen in $r d a / r d a$ utricles $(\boldsymbol{C}, \boldsymbol{D})$; asterisks indicate giant fused stereocilia. Utricles were labeled with phalloidin (magenta) and stained with anti-acetylated tubulin (cyan) and anti-ELMOD1 (green) antibodies. $\boldsymbol{E}-\mathbf{G}$, Confocal images of vestibular $(\boldsymbol{E}, \boldsymbol{F})$ or cochlear $(\boldsymbol{G})$ hair bundles from mice electroporated in utero with a GFP-ELM0D1 construct at E11.5 and dissected at P1 $(\boldsymbol{E}, \boldsymbol{G})$ or P6 $(\boldsymbol{F})$. Utricles and cochleae were labeled with phalloidin (magenta) and stained with anti-GFP antibody (green) to amplify GFP-ELMOD1 fluorescence. Panel full widths: $\boldsymbol{A}-\boldsymbol{D}, 25 \mu \mathrm{m} ; \boldsymbol{E}, 40 \mu \mathrm{m} ; \boldsymbol{F}, \mathbf{G}, 50 \mu \mathrm{m}$. nuclei were lower in the epithelium and the cells were longer, allowing for more accurate quantitation.

\section{Results \\ ARF family and ARF modulator expression}

To determine whether ELMOD1 plays a unique role in hair cells, we examined expression of ARFs and ARF modulators like ELMOD1 in hair cells. We analyzed data from experiments that performed RNA-seq measurements of transcript abundance on sorted mouse cochlea and utricle hair cells from the Pou4f3-Gfp mouse line (Shen et al., 2015). In utricle (Fig. 1A), of all ARFs and ARF modulators, only Elmod1 was enriched 10-fold or greater in hair cells; in cochlea, only Adap1 and Elmod1 were enriched tenfold or greater, with Elmod 1 at a 360-fold higher level (Fig. 1B). These experiments showed that Elmod 1 was consistently enriched in hair cells, more so than any other ARFs or ARF modulators.

We also examined protein levels of ARFs and ARF regulators (Fig. 1C). In mouse utricle extracts (Krey et al., 2015), we detected the ARF family members ARF1-4 (combined because of ambiguity from shared peptides), ARF6, ARL3, and ARL8A. We detected several ARF modulators, but did not reliably observe ELMOD1 in mouse inner-ear samples using mass spectrometry. That discrepancy with transcriptomics experiments likely reflects the difference in sensitivity and dynamic range between the two approaches. two separate experiments with images from two utricles per condition were acquired.

Transmission electron microscopy. Utricles from P5 or P12 $+/ r d a$ or $r d a / r d a$ mice were immersion-fixed in $1 \%$ glutaraldehyde, $1 \% \mathrm{OsO}_{4}, 0.1$ $\mathrm{M}$ phosphate for $3 \mathrm{~h}$, dehydrated in a graded series of acetone, and embedded in Araldite (Electron Microscopy Sciences). The Araldite was cured in a $60^{\circ} \mathrm{C}$ oven for $48 \mathrm{~h}$. Sections of $90 \mathrm{~nm}$ were collected on Maxtaform 200-mesh Cu/Rh grids (Ted Pella), were stained using 1\% uranyl acetate (Electron Microscopy Sciences) and Reynold's lead citrate, and were examined on a Philips CM100 transmission electron microscope.

Endocytosis assay using FM1-43FX. Utricles were dissected on ice, and then transferred to ice-cold HBSS containing $100 \mu \mathrm{M}$ tubocurarine to block transduction channels. Tubocurarine was also included in all subsequent solutions. Organs were incubated on ice for 1 min with $20 \mu \mathrm{M}$ FM1-43FX, rinsed briefly in cold HBSS, then were transferred to HBSS at $37^{\circ} \mathrm{C}$ for up to $1 \mathrm{~h}$. Some organs were transferred immediately to cold $4 \%$ formaldehyde for $20 \mathrm{~min}$ rather than being transferred to $37^{\circ} \mathrm{C}$. All organs were fixed on ice for $20 \mathrm{~min}$ in $4 \%$ formaldehyde, and then washed three times in cold PBS. Organs were mounted and imaged as above. Images from at least two separate experiments with one to two utricles per time point were analyzed using Fiji. The morphology of the hair cell neck region was used to distinguish between type I and type II hair cells, and ROIs were generated surrounding the cuticular plate of 10 type I hair cells per image. Measurements were then made using this ROI at intervals of five sections above and below the cuticular plate, marking measurements made at the bundle, cuticular plate, pre-nuclear, nuclear, and after nuclear levels. We only used type I hair cells for this analysis as their

\section{Expression of ELMOD1 in utricles}

Although ELMOD1 was not detected by mass spectrometry, a sensitive antibody against ELMOD1 readily detected a band of the correct molecular mass $(38 \mathrm{kDa})$ in utricle hair bundles, whole utricle, and brain extracts (Fig. $2 A, B$ ). The $38 \mathrm{kDa}$ band disappeared in bundles or whole utricle of $r d a / r d a$ mice (Fig. $2 A$ ). Although several bands of higher molecular mass persisted in brain extracts of $r d a / r d a$ mutants, the $38 \mathrm{kDa}$ band disappeared completely (Fig. 2B). ELMOD1 was detected in mouse utricle as early as embryonic day (E)18, and the ELMOD1-to-actin ratio increased across postnatal development, with peak levels of expression at P7 (Fig. 2B).

Because loss of ELMOD1 might lead to changes in protein content detectable by mass spectrometry, we used multiplex quantitation with isobaric chemical tags (Thompson et al., 2003) to analyze quantitatively the $\sim 2000$ most abundant proteins of the utricle and determine whether there were any significant changes in protein abundance resulting from the $r d a$ mutation. Proteins were isolated from $r d a / r d a$ or $r d a /+$ utricles and digested with trypsin; peptides were then labeled with TMT isobaric reagents, subjected to mass spectrometry using an instrument with an Orbitrap detector, and quantified by comparison of tag ion intensities. Proteins with two or more independent peptides that were detected in each sample showed little change between the two genotypes 


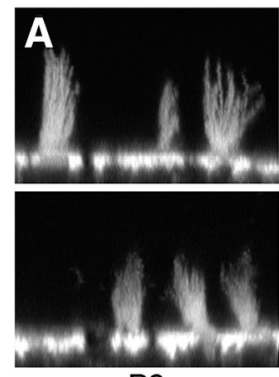

$\mathrm{P} 2$
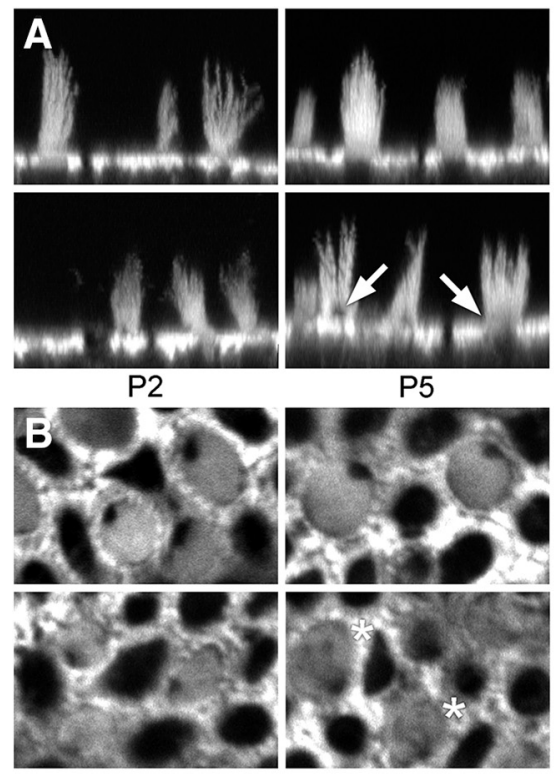

P5
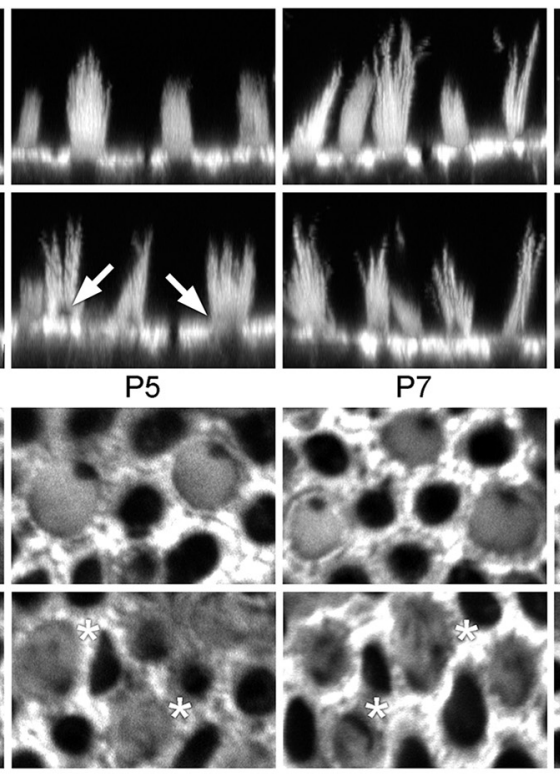

P7

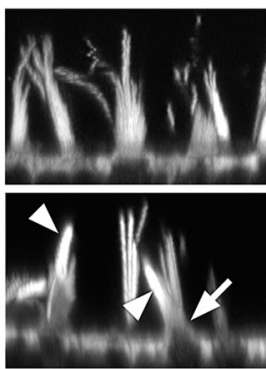

P12
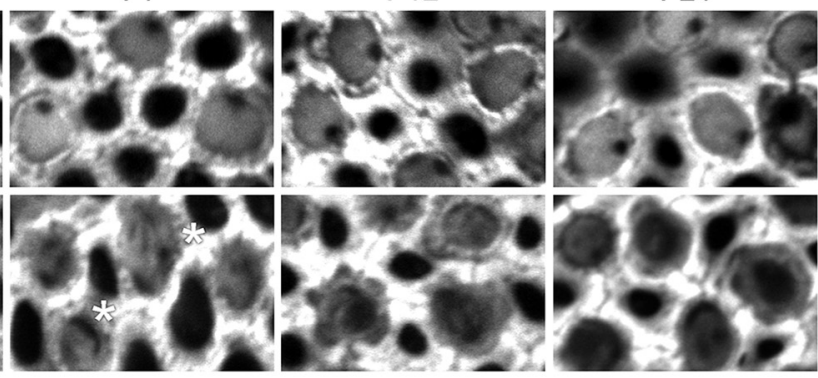

$+/ r d a$

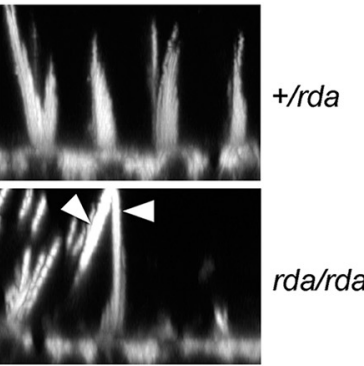

$\mathrm{P} 21$

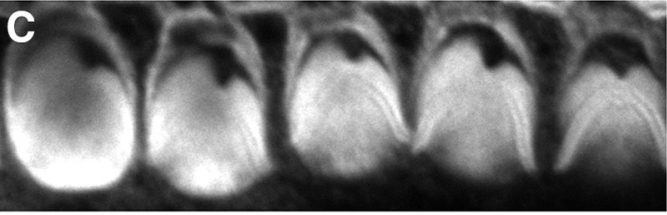

$+/$ rda
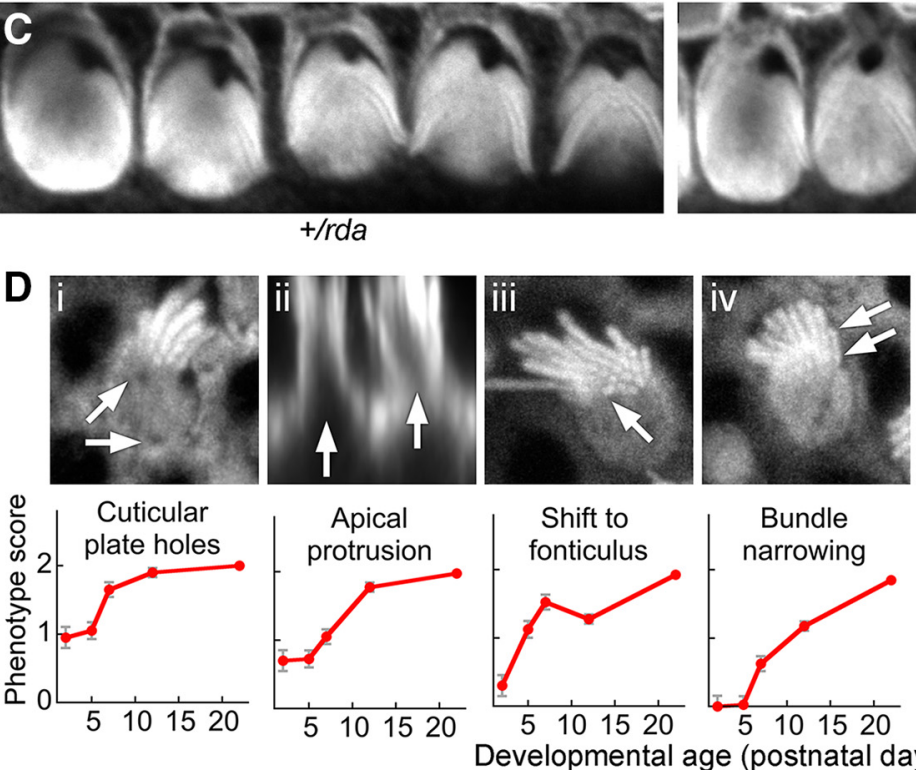

ge (postnatal days)

Figure 4. Progressive actin structural defects in $r d a / r d a$ vestibular hair cells. All images use phalloidin to stain actin. $A$, Confocal images of phalloidin-labeled vestibular hair bundles from $+/ r d a$ (top) or rda/rda (bottom) mice at various postnatal ages. Arrows mark protrusions of the cell from the apical surface (beginning at P5) and arrowheads indicate fused stereocilia (beginning at P12). Panel full widths: $30 \mu \mathrm{m} . \boldsymbol{B}$, Cuticular plates of vestibular hair cells degrade between P5 and P21 in rda/rda mice. Confocal images at the level of the cuticular plate of phalloidin-labeled vestibular hair cells from $+/ r d a$ (top) or $r d a / r d a$ (bottom) mice at various postnatal ages. Asterisks mark holes within the cuticular plate actin that develop starting at P5, indicating that cuticular plate degradation precedes stereocilia fusion in rda/rda mice. Panel full widths: $15 \mu \mathrm{m}$. C, Cuticular plates of cochlear outer hair cells show some degradation at P5 in rda/rda mice. Asterisks are adjacent to holes within the cuticular-plate actin. Panel full widths: $35 \mu \mathrm{m}$. D, Progression of the rda/rda phenotype. Top, Examples of each structural change occurring in rda/rda hair cells. Di, Holes in the cuticular plate; Dii, protrusion of the apical surface; Diii, shift of the bundle to the fonticulus; Div, narrowing of cross-sectional area of bundle; Dv, increased proportion of long stereocilia in bundle; and Dvi, fusion of stereocilia. Arrows indicate examples of the structural changes. Di, Diii, Div, and Dvi are $x$-y cross-sections from $z$-stacks; Dii and Dv are projections of $x$-z reslice stacks. Panel full widths: Di, $10 \mu \mathrm{m}$; Dii, $25 \mu \mathrm{m}$; Diii, $10 \mu \mathrm{m}$; Div, $10 \mu \mathrm{m} ;$ Dv, $25 \mu \mathrm{m}$; Dvi, $10 \mu \mathrm{m}$. Bottom, Quantitation of progression over development for each phenotype. Hair cells were scored 0, 1, or 2 for no phenotypic change, moderate change, or extensive change; mean \pm SEM are indicated ( $n=20$ for $\mathrm{PO} ; n=40$ for all other time points).

(Fig. 2C); indeed, a volcano plot showed that none of the differences were significant (Fig. 2D). Multiple ARF family members (ARF1, ARF4, ARF5, ARF6, ARL1, ARL3, ARL8A, and ARL8B) were detected in these experiments, but ELMOD1 was not, consistent with its low expression level. Mutation of Elmod1 thus does not lead to large-scale changes in the utricle proteome.

\section{Localization of ELMOD1}

We localized ELMOD1 in P21 utricles, where it was enriched in hair cells with a substantial concentration in the soma's apex (Fig.
$3 A, B)$. This apical labeling was punctate, reminiscent of intracellular membranes (Fig. 3B). No ELMOD1 signal was observed in $r d a / r d a$ utricles (Fig. $3 C, D$ ). The phenotype originally reported for $r d a / r d a$ cochlear hair cells, where stereocilia were fused and elongated (Johnson et al., 2012), was also seen in $r d a / r d a$ utricle hair cells (Fig. 3C). Similar ELMOD1 localization results were seen with utricles from younger animals, but nonspecific binding of the antibody was more prominent then.

We used in utero electroporation of GFP-ELMOD1, detected with anti-GFP for increased sensitivity, to examine where exoge- 

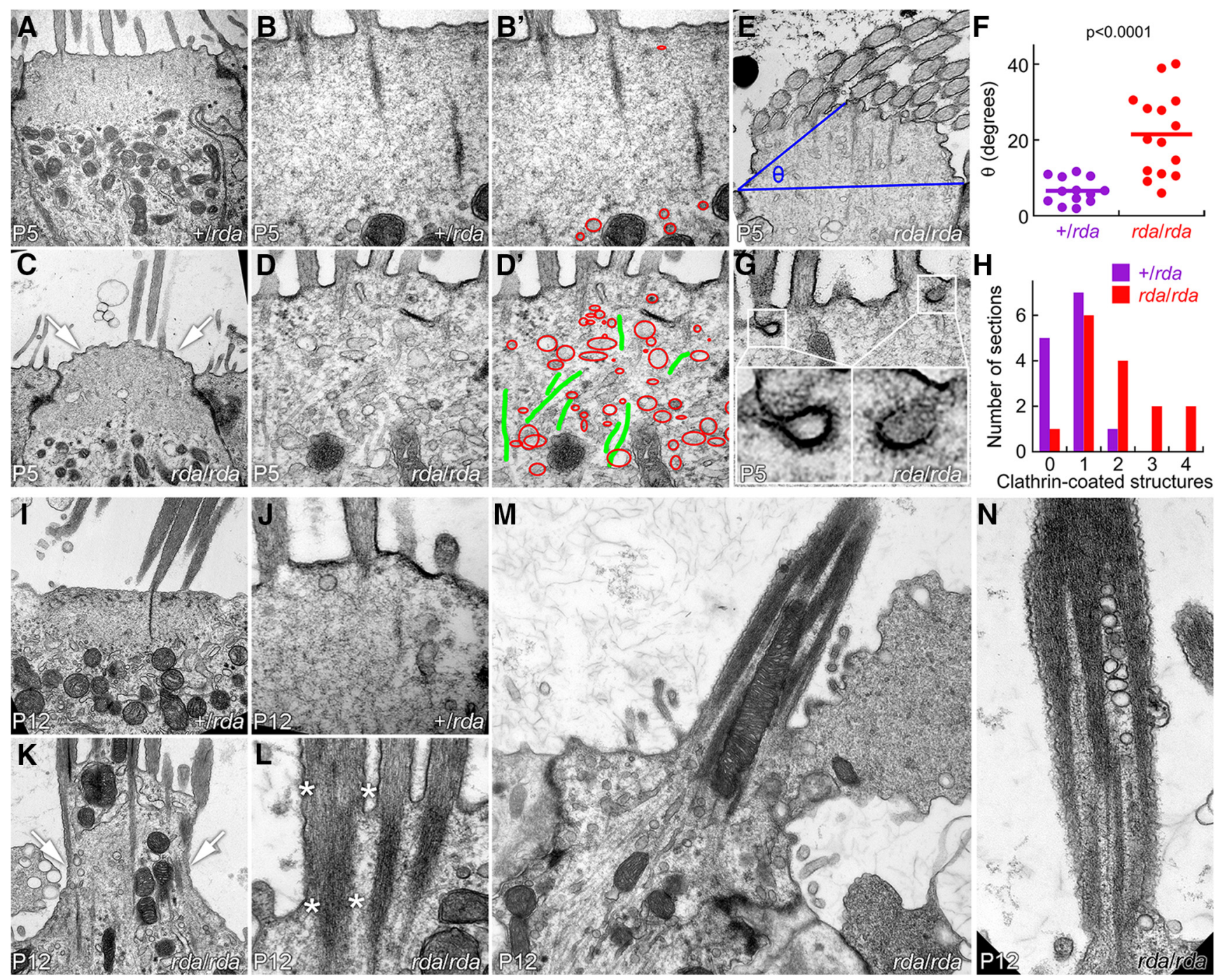

Figure 5. Accumulation of apical vesicles and progressive stereocilia fusion in $r d a /$ rda vestibular hair cells. $\boldsymbol{A}-\boldsymbol{B},+/ r d a$ vestibular hair cells at P5. $\mathbf{C}-\boldsymbol{D}$, rda/rda vestibular hair cells at P5. Notice bulging of apical membrane (arrows) and penetration of vesicular structures into the cuticular plate region (outlined in red). $\boldsymbol{B}^{\prime}, \boldsymbol{D}^{\prime}$, Vesicular structures (red) and microtubules (green) overlaid on $\boldsymbol{B}$ and $\boldsymbol{D}$ images. $\boldsymbol{E}$, Definition of angle $\theta$. A line was drawn connecting the apical end of the tight junctions on either side of the cell, and a second line was drawn from one tight junction to the apical surface halfway across the cell. $\theta$ is the angle defined by those two lines. $\boldsymbol{F}$, Increase in $\theta$ measured from $r d a / r d a$ hair cells. $G$, Examples of clathrin-coated pits and vesicles in $r d a / r d a$ hair cells. $\boldsymbol{H}$, Quantitation of clathrin-coated pits and vesicles. The $x$-axis indicates the number of clathrin structures seen in a single section, whereas the $y$-axis indicates the number of sections with that number of clathrin structures. $\boldsymbol{I}, \boldsymbol{J},+/$ rda vestibular hair cells at P12.I,, $\mathbf{P} 12+/$ rda hair cells. $\boldsymbol{K}-\boldsymbol{N}, \mathrm{P} 12 \mathrm{rda} /$ rda vestibular hair cells. Notice massive extrusion of the cell's apical domain $(\boldsymbol{K}$, arrows; see also extrusion of apical membrane in $\boldsymbol{M}$ ) and fusion of stereocilia actin cores ( $\boldsymbol{L}$, asterisks; see also $\boldsymbol{N}$ ). Panel full widths: $\boldsymbol{A}, \boldsymbol{C}, \boldsymbol{I}, \boldsymbol{K}, 4 \mu \mathrm{m} ; \boldsymbol{B}, \boldsymbol{D}, \boldsymbol{J}, \boldsymbol{L}, 1.2 \mu \mathrm{m} ; \boldsymbol{E}, 2.5 \mu \mathrm{m} ; \boldsymbol{G}, 1.2 \mu \mathrm{m} ; \boldsymbol{M}, 5 \mu \mathrm{m}$; $N, 1.5 \mu \mathrm{m}$.

nously expressed ELMOD1 distributed in hair cells. When GFPELMOD1 was electroporated into E11.5 otocysts and examined at P1 (Fig. 3E) or P6 (Fig. 3F), GFP-ELMOD1 localized to the hair bundle, kinocilium, and cell body of utricle hair cells, but was notably enriched at the apex of the cell, especially in the region of the cuticular plate. We occasionally detected GFP-ELMOD1 expression in cochlear hair cells. To provide higher-resolution localization of GFP-ELMOD1 there, we used image-scanning microscopy with an Airyscan detector (Müller and Enderlein, 2010; Sheppard et al., 2013; Roth et al., 2016). Some anti-GFP signal was detected in the stereocilia membrane of outer hair cells, but the anti-GFP signal was much brighter in tubular structures in the cells' somas (Fig. 3G).

\section{Degeneration of hair bundles and cuticular plates in $r d a / r d a$ utricles}

Actin structures of hair bundles and apical surfaces of $\mathrm{P} 2 \mathrm{rda} / \mathrm{rda}$ utricles appeared to be very similar to those of heterozygote controls
(Fig. 4). Although $r d a / r d a$ stereocilia appeared normal at P5 and P7 (Fig. 4A), hair cells' apical surfaces protruded modestly (Fig. $4 A$, arrows) and gaps were present within the actin mesh of the cuticular plate (Fig. $4 B$, asterisks). These gaps in the cuticular plate were larger in P12 and P21 utricle hair cells (Fig. $4 B$ ), and were also detected in cochlear outer hair cells of P5 rda/rda mice (Fig. 4C). Utricles from P12 and P21 rda/rda mice contained fused and elongated stereocilia (Fig. $4 A$, arrowheads), similar to those seen in IHCs from $r d a / r d a$ mice. We did not note any differences in the frequency of these $r d a / r d a$ phenotypes between type I and type II hair cells, nor between hair cells of striolar and extrastriolar regions.

We identified six structural changes that occurred in $r d a / r d a$ hair cells between P0 and P21 (Fig. 4D), including: (1) appearance of holes in the cuticular plate; (2) apical protrusion of the cell cytoplasm above the level of the circumferential actin belt; (3) shift of the hair bundle from the center of the apical surface to the fonticulus, which is the opening in the cuticular plate at the 

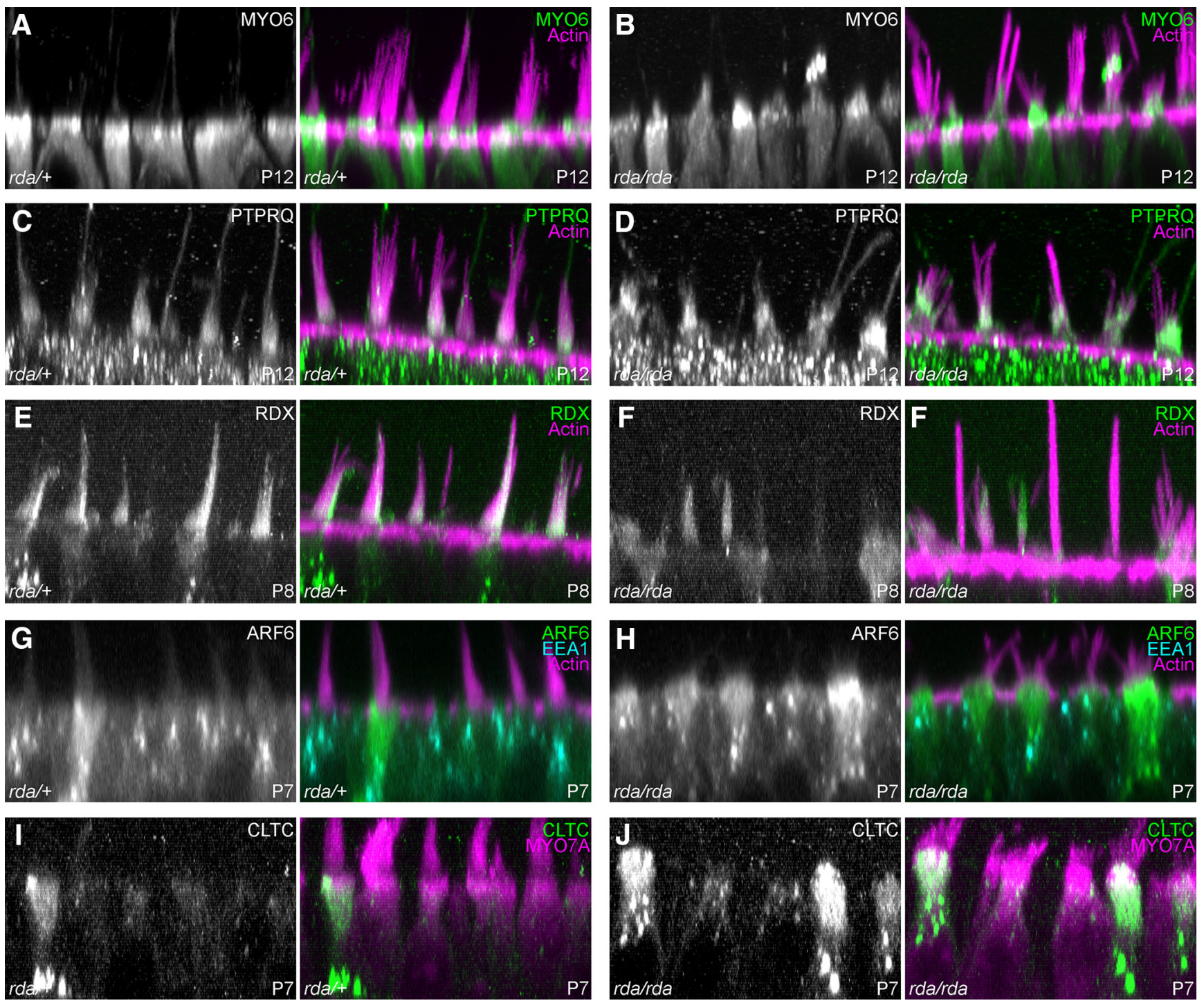

Figure 6. Localization of proteins in $r d a / r d a$ vestibular hair cells. Reslice projections of confocal $z$-stacks of phalloidin- and antibody labeled vestibular hair cells from $+/ r d a($ left) or $r d a / r d a ~(r i g h t)$ mice. $A, B$, MY06 in P12 utricle hair cells; maximum projection of $5 \mu \mathrm{m}$ depth. MY06 is present in the apical protrusions of $r d a / r d a$ hair cells. $C, D, P T P R Q$ in P12 utricle hair cells; maximum projection of $5 \mu \mathrm{m}$ depth. PTPRQ is also present in the apical protrusions of $r d a / r d a$ hair cells, and in an expanded zone in hair bundles. $E, F, R D X$ in P8 utricle hair cells; average projection of $8 \mu \mathrm{m}$ depth. ARF6 is more apically located in rda/rda hair cells. $\mathbf{G}, \boldsymbol{H}, \mathrm{ARF} 6$ and EEA1 in P7 utricle hair cells; average projection of $0.8 \mu \mathrm{m}$ depth. ARF6 is more apically located in rda/rda hair cells. I, J, CLTC in P7 utricle hair cells; average projection of $8 \mu \mathrm{m}$ depth. Increased number of high-expressing cells in rda/rda utricles. Panel full widths: $40 \mu \mathrm{m}$.

kinocilium; (4) narrowing of the cross-sectional area of the bundle, presumably because of the loss of some stereocilia; (5) an increased proportion of long stereocilia in a hair bundle, presumably due to loss of short ones; and (6) fusion of stereocilia actin cores. We quantified these changes over early postnatal development of $r d a / r d a$ hair cells, which indicated that the changes occurred in sequence (Fig. 4D). Cuticular plate disruption was the earliest observable structural change, whereas stereocilia fusion occurred later in utricle development.

Transmission electron microscopy imaging of $\mathrm{P} 5$ utricles, before stereocilia fusion, showed that the number and density of vesicles and endosome-like structures below the hair bundle increased substantially in $r d a / r d a$ mice (Fig. $5 A-D$ ); the cuticular plate appeared to be porous or missing, and many membranous structures were present where the cuticular plate normally sits (Fig. $5 B^{\prime}, D^{\prime}$ ). Apical membranes had lifted substantially above the level of the tight junctions in $r d a / r d a$ hair cells. We defined an angle $\theta$ that is defined by the elevation of the middle of apical surface above a line drawn between the tight junctions on either side of the cell (Fig. 5E). The plane of the section will affect the value of $\theta$; these deviances should average out, however, and will affect sections from control and mutant tissues similarly. $\theta$ Was $>3$-fold larger in $r d a / r d a$ hair cells compared with heterozygote controls (Fig. 5F; $p<0.0001$ by Student's $t$ test). We also noted that clathrin-coated pits and vesicles were found more frequently in $r d a / r d a$ than in heterozygous hair cells (Fig. 5G,H).

By P12, utricles from $r d a / r d a$ mice had extensive degradation of the cuticular plate and protrusion of microtubules, mitochondria, and vesicles up toward the apical surface (Fig. 5I-L). The apical membrane in many cases blebbed outward in large structures (Fig. $5 M$ ). Stereocilia appeared to be partially swallowed by the expanding membrane and had fused, either just at their bases (Fig. $5 K, L$ ) or throughout their length (Fig. $5 M, N$ ). Mitochondria and vesicles were also found within the fused stereocilia (Fig. $5 M, N)$. 

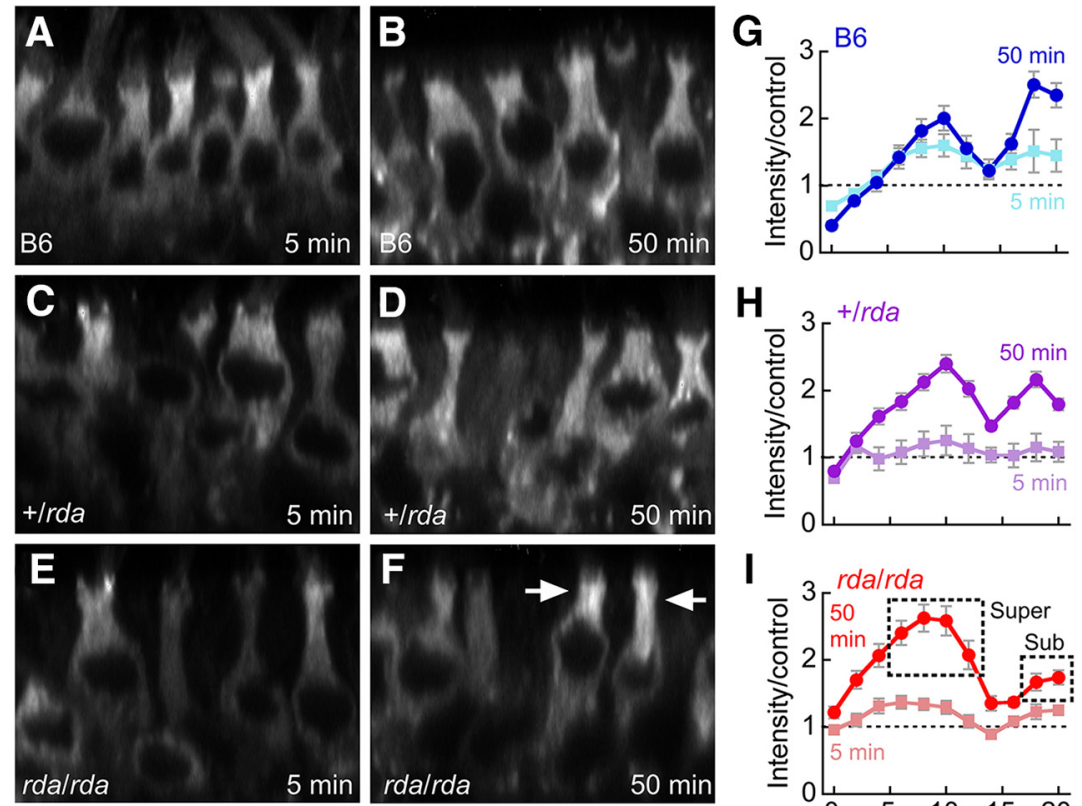

\section{西}

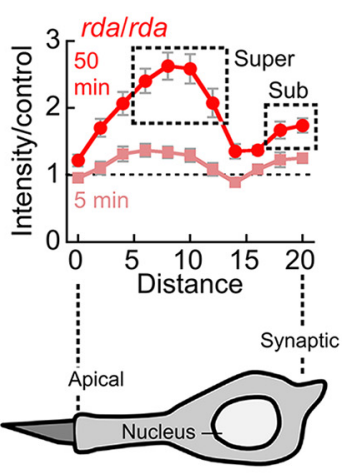

Type I hair cell

of many P7 hair cells (Fig. 6H). By contrast, the distribution of EEA1, an early endosome marker, was unchanged between heterozygous and homozygous mice (Fig. $6 G, H)$. The frequency of cells expressing high levels of clathrin heavy chain (CLTC) increased in $r d a / r d a$ mice (Fig. $6 I, J$ ); quantitation at the level of the cuticular plate indicated that whereas $+/ r d a$ heterozygous hair cells had a CLTC fluorescence signal of $3910 \pm 1490$ (arbitrary fluorescence units; mean $\pm \mathrm{SD}, n=50$ ), the CLTC signal in $r d a / r d a$ hair cells was significantly $(p<$ $0.001)$ higher at $6030 \pm 3290(n=50)$. C57BL/6 hair cells had a CLTC signal of $4810 \pm 980(n=50)$, which was also significantly different from that of $r d a / r d a$ hair cells $(p=0.013)$.

Membrane trafficking in $r d a / r d a$ mice We used FM1-43 labeling to monitor membrane trafficking in type I hair cells (Fig. 7). When transduction-channel blockers are included in the bathing solution, FM dyes enter cells via endocytosis rather than transduction (Griesinger et al., 2002; Meyers et al., 2003). We incubated dissected utricles with the fixable dye FM1-43FX for $1 \mathrm{~min}$ at $4^{\circ} \mathrm{C}$, then transferred the organs to a dye-free solution at $37^{\circ} \mathrm{C}$. Because the utricle's apical membrane is exposed to extracellular solutions while the basolateral membrane is protected by apical tight junctions and the basal lamina, most dye labeling occurs through apical endocytosis, as demonstrated by the measured labeling profiles. To examine membrane trafficking in hair cells, utricles were fixed at various times after the initial pulse of dye; the resulting distribution of dye reflected membrane trafficking in the cell. In this assay, hair cells were much more P8 C57BL/6, +/rda, and $r d a / r d a$ vestibular type I hair cells at 5 and 50 min. Each panel is an $x$-z reslice from a confocal stack. Arrows in $\boldsymbol{F}$ show accumulation of FM1-43 in prenuclear regions in rda/rda mutants at $50 \mathrm{~min}$. All panels are $40 \mu \mathrm{m}$ wide. $\mathbf{G}-\boldsymbol{I}$, Quantitation of FM1-43 labeling in type I vestibular hair cells. Diagram of hair cell shows approximate location of each point along the cell. Labeling was performed for $1 \mathrm{~min}$ at $4^{\circ} \mathrm{C}$, then samples were shifted to $37^{\circ} \mathrm{C}$ for the indicated times. Fluorescence intensity profiles are normalized to profiles from samples that were labeled for $1 \mathrm{~min}$ at $4^{\circ} \mathrm{C}$, and then fixed. Points quantified for $\boldsymbol{J}$ and $\boldsymbol{K}$ are indicated by boxes in $I . J$, Ratio of supernucleus to subnucleus staining at $5 \mathrm{~min}$. $\boldsymbol{K}$, Ratio of supernucleus to subnucleus staining at 50 min. ${ }^{* *} p<0.001 ;{ }^{* *} p<0.01$.

Expression of ARF6, PTPRQ, and MYO6 in $r d a / r d a$ utricles Mutations in Myo6, Ptprq, and Rdx each lead to a hair-cell phenotype that includes apical membrane lifting and stereocilia fusion (Self et al., 1999; Kitajiri et al., 2004; Goodyear et al., 2012), which is similar to the phenotype observed in $r d a / r d a$ mice. MYO6 and PTPRQ were both mildly mislocalized in $r d a / r d a$ mice (Fig. $6 A-D)$, although much of the altered distribution appeared to be due to the protrusion of the apical membrane along stereocilia actin cores. The extent of PTPRQ labeling on stereocilia membranes was increased somewhat toward stereocilia tips (Fig. 6D). Cell-tocell RDX labeling was variable in $r d a / r d a$ utricles (Fig. $6 F$ ), but did not differ systematically from that of heterozygote controls (Fig. 6E). Note that in Figure $6 F$ we captured several completely fused stereocilia cores of $r d a / r d a$ hair cells standing vertically, demonstrating the extreme morphology of the homozygous mutant.

Because ELMOD1 is reported to be an ARF6 GAP, we also examined ARF6 labeling in $r d a / r d a$ mice. In P7 control hair cells, ARF6 was broadly located in the apical half of hair cells, with some dense structures in supranuclear areas (Fig. 6G); by contrast, in $r d a / r d a$ mice, ARF6 was notably focused at the apical end robustly labeled than were supporting cells; dye was mostly located above the nucleus at $5 \mathrm{~min}$ post-labeling, whereas by $50 \mathrm{~min}$ there was considerable dye below the nucleus, in the synaptic region of the cell (Fig. $7 A-F$ ).

The extent of FM1-43FX dye transport within hair cells was diminished in $r d a / r d a$ mice. We analyzed the distribution of dye over time in type I hair cells, recognized by their narrow neck above the nucleus and below the cuticular plate. We found that compared with B6 and $+/ r$ da controls (Fig. $7 G-I$ ), levels of FM1-43 in the synaptic region were reduced in $r d a / r d a$ mice, and levels were elevated above the nucleus (Fig. 7F, arrows). We compared intensities in apical regions of the cell, above the nucleus ("supernucleus") to synaptic regions ("subnucleus"). Although the genotypes did not vary at $5 \mathrm{~min}$ (Fig. $7 J$ ), the super/subnuclear ratio was significantly elevated in $r d a / r d a$ hair cells compared with $+/ r d a$ or B6 controls (Fig. $7 K$ ). We noted that this ratio was also significantly elevated in $+/$ rda compared with B6 controls (Fig. $7 K$ ).

\section{ARF6-GTP labeling peaks at P8 in developing utricles}

ARF6 protein levels were relatively constant over utricle development as shown by immunoblotting (Fig. 8A) and immunocyto- 
chemistry (Fig. $8 B-D, H-J$ ). ARF6 was significantly elevated at the cuticular plate level at P8, however, compared with P5 (Fig. $8 H-L, N)$. We also examined the distribution of activated ARF6 using an ARF6-GTP antibody (Torii et al., 2014; Reviriego-Mendoza and Santy, 2015). Levels of ARF6-GTP peaked around P8 (Fig. $8 E-G, K-M, O)$, which is close to the peak of ELMOD1 expression (Fig. 2). ARF6-GTP was present at basolateral membranes in most cells (e.g., Fig. $8 K$ ), but many cells, particularly at P8, had elevated ARF6GTP surrounding the cuticular plate (arrows, Fig. $8 L$ ). ARF6-GTP at the cuticular plate level was significantly elevated at P8 compared with P12 but not P5 (Fig. 8O). Thus both ARF6 and ARF6-GTP peak at the cuticular plate level $\sim \mathrm{P} 8$, similar to the peak of ELMOD1 expression (Fig. $2 B)$.

\section{Trafficking proteins in hair cells}

Given the importance of ARF6 in apical membrane recycling and the possible role of ELMOD1 in regulating ARF6, we investigated in hair cells several other components of recycling pathways for apical membranes (Fig. 9). As previously noted, ARF6 was focused in the apical half of the hair cell, with some concentration in bright spots just above the nucleus (Fig. 9A,G). Consistent with ARF6's role in clathrin-mediated endocytosis (Doherty and McMahon, 2009), the clathrin subunit CLTC had a very similar pattern to that of ARF6, with apical concentration and supranuclear aggregates (Fig. 9B, $H$ ). Aggregates containing the early endosome marker EEA1 were more numerous than those labeled for ARF6; we also noted that EEA1 staining was considerably deeper in type I hair cells compared with type II, consistent with their deeper nuclei (Fig. 9C,I). LAMP1, which marks lysosomes, had a similar distribution to ARF6 in type I but not type II cells, where there were fewer large aggregates. RAB11, a marker of apical recycling endosomes, and RAB5, which localizes to apical early endosomes, were more uniformly distributed in hair cells (Fig. $9 E-K, F-L)$, unlike the distribution of ARF6. Thus ARF6 appears to be associated with a subset of apical endosomal compartments, as well as with lysosomes, although more direct experiments would be required to prove this interaction.

\section{ARF6 GTP/GDP ratio is elevated in $r d a / r d a$ utricles}

If ELMOD1 is an ARF6 GAP, the GTP/GDP ratio for ARF6 should be increased in $r d a / r d a$ utricles. To measure ARF6-GTP levels, we performed pulldowns using the protein-binding domain (PBD) of the ARF6 effector protein GGA3, which binds GTP-bound ARF6 (Takatsu et al., 2002). We precipitated ARF6GTP from utricle protein extracts with immobilized PBD-GGA3, then detected ARF6 with a specific antibody (Fig. 10A). Comparing precipitated ARF6 to total ARF6, we estimated that the ARF6 GTP/GDP ratio was elevated $\sim 4$-fold in P12 $r d a / r d a$ utricles compared with heterozygotes or B6 controls (Fig. 10B), confirming ELMOD1's role as an ARF6 GAP in hair cells.

We corroborated this result using immunocytochemistry with the ARF6-GTP antibody. Although there was substantial cell-to-cell variability, at P8 the distribution of total ARF6 signal was modestly but significantly different in $r d a / r d a$ cuticular plates compared with $+/ r d a(p=0.023$; Fig. $10 E-H)$. By contrast, the frequency of $r d a / r d a$ cells with elevated ARF6-GTP was noticeably greater than in controls. We noted that the distribution of ARF6-GTP signal intensities at the cuticular plate level was shifted to substantially higher intensities in $r d a / r d a$ hair cells compared with $+/ r d a(p<0.001$; Fig. $10 I-L)$, consistent with the lack of ELMOD1 GAP activity.

\section{ARF6-GTP levels are correlated with the $r d a / r d a$ phenotype} We compared the phenotypes of $160 \mathrm{rda} / \mathrm{rda}$ cells to their ARF6GTP levels (Fig. 10C,D) using the same qualitative measures of the $r d a / r d a$ structural changes described for Figure $4 D$. Each cell was graded $0-2$ for each structural change, and scores for all changes were combined to generate an overall phenotype score for that cell. Combining type I and II hair cells, we found that the ARF6-GTP intensity rose as the phenotype score increased (Fig. $10 D$ ), although the (few) cells with the most disrupted morphology had low ARF6-GTP levels. We noted that whereas $\sim 40 \%$ of 

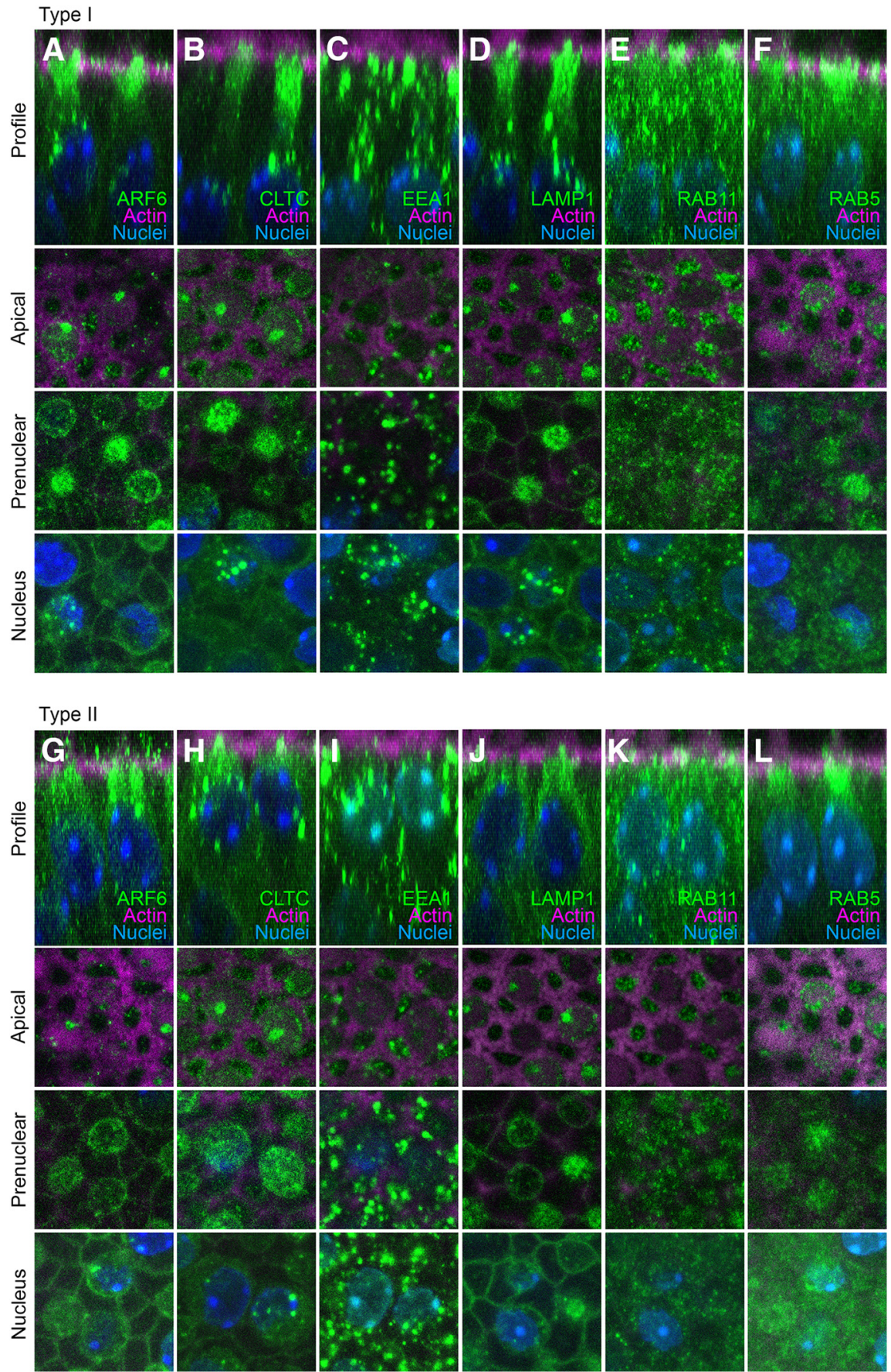

Figure 9. Hair-cell localization of proteins involved in apical membrane trafficking. Displayed for each protein (in type I or type II hair cells) are an $x$-z reslice showing the protein's apical-basal profile, as well as $x$-y slices at apical, prenuclear, and nuclear levels. A-F, Type I hair cells. G-L, Type ll hair cells. A, G: ARF6. B, H: CLTC. C, I: EEA1. D, J: LAMP1. E, $\boldsymbol{K}$ : RAB11. $\boldsymbol{F}$, L: RAB5. Panel full widths: $18 \mu \mathrm{m}$.

the type I cells had high ARF6-GTP levels, ARF6-GTP was elevated in only $\sim 20 \%$ of type II cells.

\section{Discussion}

We show here that ELMOD1 acts as a GTPase-activating protein for ARF6 in hair cells, and its developmentally regulated GAP activity is required to stabilize apical structures of hair cells. The $r d a$ mutation, which causes the complete loss of ELMOD1 protein, leads to a hair-cell phenotype that includes fused and elongated stereocilia, degenerating cuticular plates, altered apical endocytosis, and inhibition of vesicle trafficking. These results suggest that the maintenance of both cuticular plate and stereocilia structures in hair cells requires conversion of ARF6 to the GDP-bound form, at least at the apical surface and at the appropriate time in development.

\section{Biasing ARF6 to the GTP-bound form underlies the $r d a / r d a$ phenotype}

ARF proteins are generally thought to be inactive in the GDP-bound state, requiring GEFs for activation and GAPs for subsequent inactivation (Gillingham and Munro, 2007); biochemical evidence showed that ELMOD1 is an ARF6 GAP in vitro (Ivanova et al., 2014). RNA-seq and localization experiments suggest that ELMOD1 is substantially enriched in hair cells over supporting cells in the utricle, which we confirmed using immunocytochemistry. Moreover, the loss of ELMOD1 substantially increased levels of ARF6-GTP, suggesting that ELMOD1 is the dominant ARF6 GAP in the utricle.

ELMOD1, ARF6, and ARF6-GTP all concentrate at the apical pole of the hair cell between $\mathrm{P} 5$ and P12, with levels peaking $\sim$ P8 in wild-type utricles. In the absence of ELMOD1, elevated ARF6-GTP levels are seen in a much higher fraction of P8 cells than in wild-type mice, and ARF6GTP levels correlate with the degree of phenotypic disruption. These observations suggest that ARF6-GTP must be converted to the GDP-bound form only after initial stages of hair-bundle development. Given that ELMOD1's only known biological activity is its ARF6 GAP activity, we suggest that the phenotype seen in the $r d a /$ $r d a$ mice is due to the increased ARF6-GTP levels present, and that any ELMOD1 biochemical or structural effects in hair cells are mediated through ARF6. We acknowledge that ELMOD1 might have additional, as-yet unknown biochemical functions.

\section{Control of the actin cytoskeleton by ELMOD1 and ARF6}

ARF6 controls cell behaviors that rely on dynamic actin rearrangement (Schwartz et al., 1998; Zhang et al., 1998; Radhakrishna et al., 1999; Boshans et al., 2000); regulation occurs through production of $\mathrm{PI}(4,5) \mathrm{P}_{2}$ and activation of members of the RHO GTPase family (Myers and Casanova, 2008). Several RHO GTPases control hair-bundle structure, including RAC1 (Grimsley-Myers et al., 2009) and CDC42 (Ueyama et al., 2014). Indeed, RHOA, RAC1, RAC3, and CDC42 can all be detected in bundles (Shin et al., 2013; Krey et al., 2015).

Activation of RHO GTPases, especially in combination with $\mathrm{PI}(4,5) \mathrm{P}_{2}$ generation, leads to increased actin dynamics and remodeling of actin structures (de Curtis and Meldolesi, 2012). The 

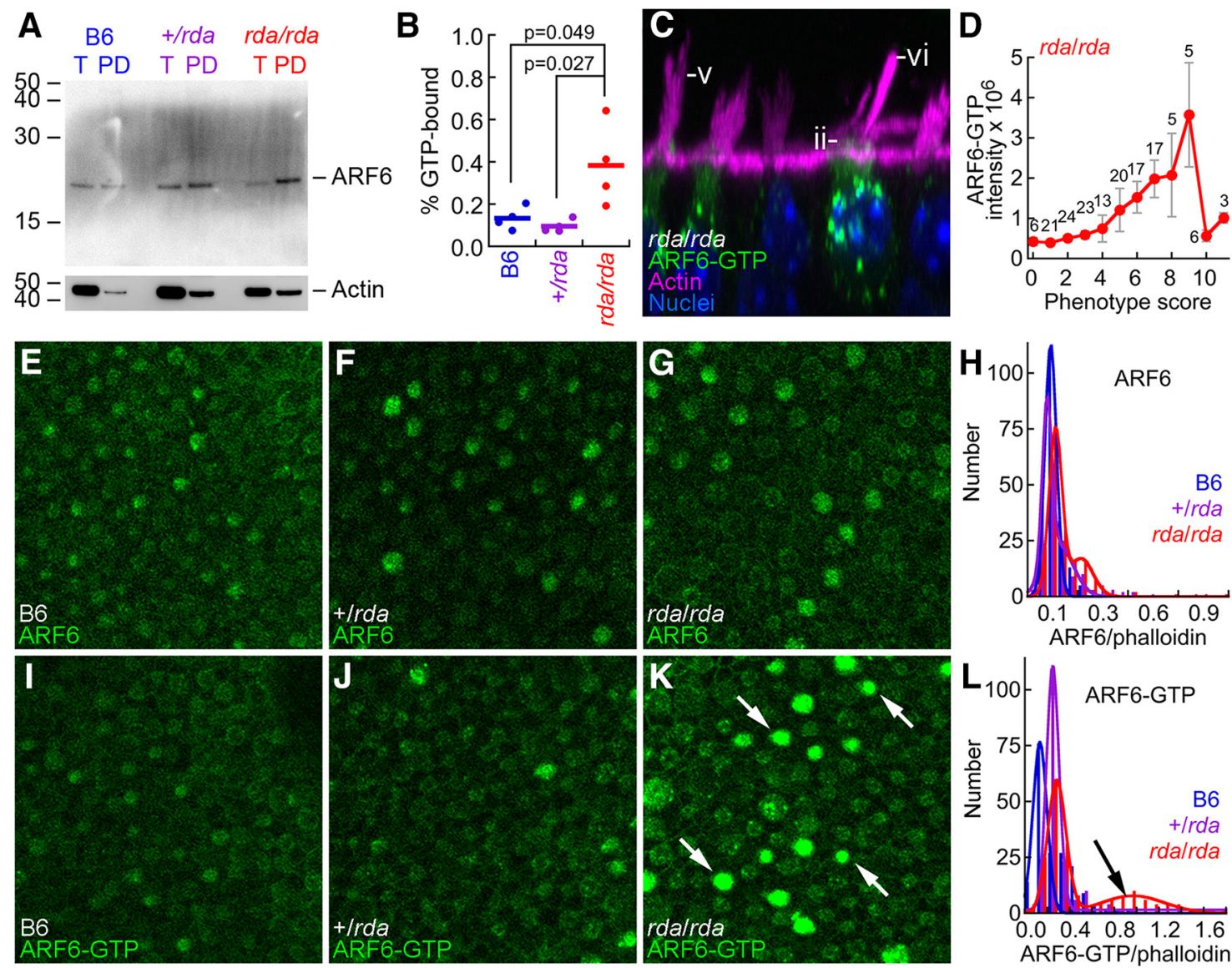

Figure 10. ELMOD1 is an ARF6 GAP in hair cells. A, Immunoblot showing total ARF6 (T) or ARF6-GTP pulled down with PBD-GGA3 (PD) from B6, +/rda, and rda/rda utricle extracts. Blot was reprobed for actin (below). T, Total material; PD, pulldown. Equal fractions of each sample were loaded, allowing direct comparison band intensity. B, Summed data from four PBD-GGA3 pulldown experiments. The fraction of ARF6 in the GTP-bound state was significantly elevated in $r d a / r d a$ utricles compared with either $+/ r d a$ or B6 utricles. $C$, The rda/rda phenotype is most pronounced in cells with high ARF6-GTP levels; examples of the rda/rda phenotype are shown. Morphology phenotypes are the same as for Figure 4: (Dii) apical cytoplasmic protrusion, (Dv) high proportion of long stereocilia in bundles, and (Dvi) fused and elongated stereocilia. Panel is $37 \times 37 \mu \mathrm{m}$. D, Correlation of summed phenotype score against average ARF6-GTP intensity. For a given cell, phenotype scores $(0-2$ scale) were summed for all six phenotype features (mean \pm SEM; number of cells with a given phenotype score are indicated above data points). $E-L$, Examples of immunocytochemistry at cuticular-plate level of hair cells for ARF6 $(\boldsymbol{E}-\boldsymbol{G})$ or ARF6-GTP $(\boldsymbol{I}-\boldsymbol{K})$, as well as quantitation of the immunocytochemistry data $(\boldsymbol{H}, \boldsymbol{L})$. $\boldsymbol{K}$, Arrows indicate rda/rda cells with high levels of ARF6-GTP. All immunocytochemistry panels are $100 \times 100 \mu \mathrm{m}$. H, L, ARF6 or ARF6-GTP signal was normalized by the phalloidin signal, then distributions were fit with double Gaussians. L, Arrow indicates the large population of $r d a / r d a$ hair cells with high levels of ARF6-GTP. +/rda and B6 mice had smaller populations of high-expressing cells.

cuticular plate, a random meshwork of actin, assembles during a hair cell's first 7-10 d (Tilney et al., 1992; Nishida et al., 1998); its formation must be accompanied by substantial actin dynamics, which could require ARF6-GTP and activated $\mathrm{RHO}$ proteins. Once the final structure of the cuticular plate has been formed, however, actin remodeling likely is suppressed; this suppression could be in part due to ELMOD1 inactivation of ARF6. Similarly, stereocilia grow during a hair cell's first 7-10 d, and undergo remodeling at their basal insertions into the hair cell to form the stereocilia taper and intracellular rootlet (Tilney et al., 1992). Overactive remodeling, e.g., when ARF6 remains activated in $r d a / r d a$ mice, may lead to the stereocilia fusion phenotype observed in these mice. By inactivating ARF6, ELMOD1 apparently controls the extent of actin remodeling in hair cells.

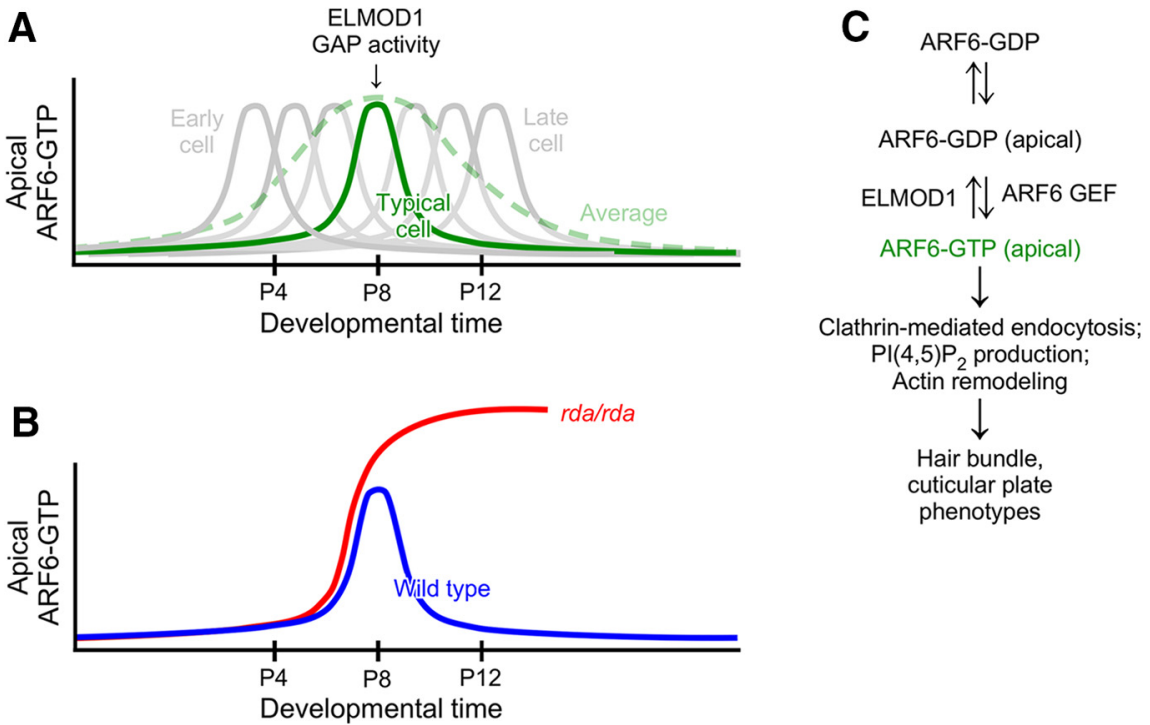

Figure 11. Model for inactivation of ARF6 by ELMOD1. A, While ARF6-GTP (and ELMOD1) levels appear to have a broad peak during development; the average response (green dashed line) obscures the sharper peaks of individual cells. ELMOD1 levels peak around the time ARF6-GTP levels do, which produces a transient ARF6-GTP response. $\boldsymbol{B}$, In the absence of ELMOD1, ARF6-GTP levels are maintained at high levels, increasing the fraction of cells that have elevated ARF6-GTP. C, Biochemical pathways for ARF6 and ELMOD1. 


\section{Control of apical membranes by ELMOD1 and ARF6}

ARF6 also modulates several vesicle-recycling pathways (D'SouzaSchorey and Chavrier, 2006; Donaldson and Jackson, 2011), including both clathrin-mediated and clathrin-independent endocytosis, as well as trafficking to recycling endosomes (Naslavsky et al., 2003) and basolateral sorting of vesicles from recycling endosomes (Shteyn et al., 2011). Recycling from the tubular endosomal membrane to the plasma membrane also requires ARF6 activation (Radhakrishna and Donaldson, 1997). Whereas effects of ARF6 on vesicle trafficking and actin organization can be distinguished by the use of ARF6 effector-domain mutants (Al-Awar et al., 2000), cytoskeleton remodeling and plasma-membrane dynamics are tightly coordinated, mediated by their codependence on $\mathrm{PI}(4,5) \mathrm{P}_{2}$ and RHO GTPases.

In $r d a / r d a$ hair cells, which have high levels of ARF6-GTP, vesicles accumulated at the apical surface of P5-P8 hair cells and basolateral trafficking of FM1-43 labeled vesicles was reduced. This phenotype resembles that of cells expressing constitutively active ARF6 mutants, such as ARF6-Q67L. Similar to $r d a / r d a$ hair cells, expression of ARF6-Q67L in polarized epithelial cells both stimulates clathrin-mediated endocytosis at the apical surface (Altschuler et al., 1999) and prevents basolateral targeting of endosomes in polarized epithelial cells (Shteyn et al., 2011). We suggest that through inhibition of ARF6, ELMOD1 normally decreases membrane trafficking in the apex of a hair cell at $\sim \mathrm{P} 7$; in $r d a / r d a$ hair cells, membrane trafficking continues unabated.

The progression of the phenotype within $r d a / r d a$ vestibular hair cells suggests that misregulation of endocytic trafficking and cuticular plate actin may drive the subsequent changes in hairbundle morphology. Before any stereocilia changes, gaps appeared in cuticular plate actin, the apical membrane lifted, and vesicles accumulated within the cuticular-plate region. As degeneration of the cuticular plate proceeded, apical surfaces protruded and the bundle shifted toward the fonticulus. With a slightly delayed time course, the cross-sectional area of the bundle decreased, perhaps as stereocilia disappeared; finally, the remaining long stereocilia fused.

\section{$r d a / r d a$ mice phenotype resembles that of Myo6, Ptprq, and $R d x$ mutants}

Sharing of phenotypes by multiple genes raises the possibility that they operate in a molecular pathway; for example, the Usher syndrome type I deafness mutants all show disorganized stereocilia, consistent with the suggestion that the Usher proteins are responsible for constructing interstereocilia linkages (Cosgrove and Zallocchi, 2014). Another common phenotype seen in hair cells is shared by Myo6, Ptprq, and $R d x$ mutants, which all have protruding apical membranes as well as stereocilia elongation and fusion (Self et al., 1999; Kitajiri et al., 2004; Goodyear et al., 2012; Seki et al., 2017). A similar phenotype is seen with conditional $C d c 42$ mutants (Ueyama et al., 2014). Utricle hair cells of $r d a / r d a$ mice share this phenotype, as do cochlear hair cells (Johnson et al., 2012). MYO6, PTPRQ, and RDX each appear to be distributed relatively normally in $r d a / r d a$ hair cells, which suggests that if the proteins are in a common pathway, then ELMOD1 acts downstream of them.

A plausible common pathway for ARF6, MYO6, PTPRQ, and RDX is regulation of or response to $\mathrm{PI}(4,5) \mathrm{P}_{2}$ levels on the hair cell's apical surface. As noted above, ARF6-GTP stimulates production of $\mathrm{PI}(4,5) \mathrm{P}_{2}$ at cell apical membranes (Donaldson and Jackson, 2011). Hair cells compartmentalize $\mathrm{PI}(4,5) \mathrm{P}_{2}$ so that levels of the lipid are very low at stereocilia tapers and apical surface, in part due to concentration of the lipid phosphatase PTPRQ at those locations (Hirono et al., 2004; Zhao et al., 2012). MYO6 is thought to localize PTPRQ at the stereocilia bases (Sakaguchi et al., 2008), whereas RDX requires a localized $\mathrm{PI}(4,5) \mathrm{P}_{2}$ signal in stereocilia (Zhao et al., 2012). MYO6 also has a high affinity binding site in its tail for PI $(4,5) \mathrm{P}_{2}$-containing liposomes (Spudich et al., 2007) and like ARF6, has been shown to regulate the trafficking of newly endocytosed vesicles (Aschenbrenner et al., 2003; Frank et al., 2004). Together, these observations suggest that $r d a / r d a$ hair cells may have altered $\mathrm{PI}(4,5) \mathrm{P}_{2}$ levels at apical surfaces, which may partly underlie the apical membrane and actin disruption seen in these cells.

\section{Model for ELMOD1 function}

The rate of hair cell production in utricle peaks $\sim$ P0 (Burns et al., 2012). ELMOD1 levels were highest at P7, which suggests that it is needed later in development to stabilize hair bundles, cuticular plates, and apical membranes (Fig. 11). The timing of ELMOD1 expression is also consistent with the onset of morphological changes in $r d a / r d a$ mice, which starts at P5. As bundles mature, there may be an increased demand for ARF6-dependent actin remodeling and apical membrane trafficking; to counteract the increased activated ARF6 levels, ELMOD1 upregulation may be needed stabilize actin structures and reduce the trafficking of endocytosed vesicles. In $r d a / r d a$ mice, excessive levels of ARF6-GTP lead to the apical accumulation of endocytosed vesicles and protrusion of the apical plasma membrane. Both of these events are preceded by breakdown of the cuticular plate, and this breakdown could lead directly to the changes in apical membrane trafficking. Fusion of stereocilia occurs later and may also be a direct result of disruption of the cuticular plate, as this structure normally anchors and separates individual stereocilia. Our results thus suggest that the principal function of ELMOD1 is to inactivate ARF6, which allows cuticular plates and stereocilia to develop their final, mature structures.

\section{References}

Al-Awar O, Radhakrishna H, Powell NN, Donaldson JG (2000) Separation of membrane trafficking and actin remodeling functions of ARF6 with an effector domain mutant. Mol Cell Biol 20:5998-6007. CrossRef Medline

Altschuler Y, Liu S, Katz L, Tang K, Hardy S, Brodsky F, Apodaca G, Mostov K (1999) ADP-ribosylation factor 6 and endocytosis at the apical surface of Madin-Darby canine kidney cells. J Cell Biol 147:7-12. CrossRef Medline

Aschenbrenner L, Lee T, Hasson T (2003) Myo6 facilitates the translocation of endocytic vesicles from cell peripheries. Mol Biol Cell 14:2728-2743. CrossRef Medline

Boshans RL, Szanto S, van Aelst L, D'Souza-Schorey C (2000) ADP-ribosylation factor 6 regulates actin cytoskeleton remodeling in coordination with Rac1 and RhoA. Mol Cell Biol 20:3685-3694. CrossRef Medline

Burns JC, On D, Baker W, Collado MS, Corwin JT (2012) Over half the hair cells in the mouse utricle first appear after birth, with significant numbers originating from early postnatal mitotic production in peripheral and striolar growth zones. J Assoc Res Otolaryngol 13:609-627. CrossRef Medline

Cosgrove D, Zallocchi M (2014) Usher protein functions in hair cells and photoreceptors. Int J Biochem Cell Biol 46:80-89. CrossRef Medline

de Curtis I, Meldolesi J (2012) Cell surface dynamics: how Rho GTPases orchestrate the interplay between the plasma membrane and the cortical cytoskeleton. J Cell Sci 125:4435-4444. CrossRef Medline

Doherty GJ, McMahon HT (2009) Mechanisms of endocytosis. Annu Rev Biochem 78:857-902. CrossRef Medline

Donaldson JG, Jackson CL (2011) ARF family G proteins and their regulators: roles in membrane transport, development and disease. Nat Rev Mol Cell Biol 12:362-375. CrossRef Medline

D'Souza-Schorey C, Chavrier P (2006) ARF proteins: roles in membrane traffic and beyond. Nat Rev Mol Cell Biol 7:347-358. CrossRef Medline

East MP, Bowzard JB, Dacks JB, Kahn RA (2012) ELMO domains, evolutionary and functional characterization of a novel GTPase-activating protein (GAP) domain for Arf protein family GTPases. J Biol Chem 287: 39538-39553. CrossRef Medline

Ebrahim S, Avenarius MR, Grati M, Krey JF, Windsor AM, Sousa AD, Ballesteros A, Cui R, Millis BA, Salles FT, Baird MA, Davidson MW, Jones SM, Choi D, Dong L, Raval MH, Yengo CM, Barr-Gillespie PG, Kachar B 
(2016) Stereocilia-staircase spacing is influenced by myosin III motors and their cargos espin-1 and espin-like. Nat Commun 7:10833. CrossRef Medline

Erde J, Loo RR, Loo JA (2014) Enhanced FASP (eFASP) to increase proteome coverage and sample recovery for quantitative proteomic experiments. J Proteome Res 13:1885-1895. CrossRef Medline

Franco M, Peters PJ, Boretto J, van Donselaar E, Neri A, D'Souza-Schorey C, Chavrier P (1999) EFA6, a sec7 domain-containing exchange factor for ARF6, coordinates membrane recycling and actin cytoskeleton organization. EMBO J 18:1480-1491. CrossRef Medline

Frank DJ, Noguchi T, Miller KG (2004) Myosin VI: a structural role in actin organization important for protein and organelle localization and trafficking. Curr Opin Cell Biol 16:189-194. CrossRef Medline

Gillespie PG, Müller U (2009) Mechanotransduction by hair cells: models, molecules, and mechanisms. Cell 139:33-44. CrossRef Medline

Gillingham AK, Munro S (2007) The small G proteins of the Arf family and their regulators. Annu Rev Cell Dev Biol 23:579-611. CrossRef Medline

Goodyear RJ, Jones SM, Sharifi L, Forge A, Richardson GP (2012) Hair bundle defects and loss of function in the vestibular end organs of mice lacking the receptor-like inositol lipid phosphatase PTPRQ. J Neurosci 32:2762-2772. CrossRef Medline

Griesinger CB, Richards CD, Ashmore JF (2002) Fm1-43 reveals membrane recycling in adult inner hair cells of the mammalian cochlea. J Neurosci 22:3939-3952. Medline

Griesinger CB, Richards CD, Ashmore JF (2004) Apical endocytosis in outer hair cells of the mammalian cochlea. Eur J Neurosci 20:41-50. CrossRef Medline

Grimsley-Myers CM, Sipe CW, Géléoc GS, Lu X (2009) The small GTPase Rac1 regulates auditory hair cell morphogenesis. J Neurosci 29:1585915869. CrossRef Medline

Hirono M, Denis CS, Richardson GP, Gillespie PG (2004) Hair cells require phosphatidylinositol 4,5-bisphosphate for mechanical transduction and adaptation. Neuron 44:309-320. CrossRef Medline

Hyman T, Shmuel M, Altschuler Y (2006) Actin is required for endocytosis at the apical surface of Madin-Darby canine kidney cells where ARF6 and clathrin regulate the actin cytoskeleton. Mol Biol Cell 17:427-437. CrossRef Medline

Ivanova AA, East MP, Yi SL, Kahn RA (2014) Characterization of recombinant ELMOD (cell engulfment and motility domain) proteins as GTPaseactivating proteins (GAPs) for ARF family GTPases. J Biol Chem 289: 11111-11121. CrossRef Medline

Jaworek TJ, Richard EM, Ivanova AA, Giese AP, Choo DI, Khan SN, Riazuddin S, Kahn RA, Riazuddin S (2013) An alteration in ELMOD3, an Arl2 GTPase-activating protein, is associated with hearing impairment in humans. PLoS Genet 9:e1003774. CrossRef Medline

Johnson KR, Longo-Guess CM, Gagnon LH (2012) Mutations of the mouse ELMO domain containing 1 gene (Elmod1) link small GTPase signaling to actin cytoskeleton dynamics in hair cell stereocilia. PLoS One 7:e36074. CrossRef Medline

Kitajiri S, Fukumoto K, Hata M, Sasaki H, Katsuno T, Nakagawa T, Ito J, Tsukita S, Tsukita S (2004) Radixin deficiency causes deafness associated with progressive degeneration of cochlear stereocilia. J Cell Biol 166: 559-570. CrossRef Medline

Klein S, Franco M, Chardin P, Luton F (2006) Role of the Arf6 GDP/GTP cycle and Arf6 GTPase-activating proteins in actin remodeling and intracellular transport. J Biol Chem 281:12352-12361. CrossRef Medline

Krey JF, Sherman NE, Jeffery ED, Choi D, Barr-Gillespie PG (2015) The proteome of mouse vestibular hair bundles over development. Sci Data 2:150047. CrossRef Medline

Manor U, Kachar B (2008) Dynamic length regulation of sensory stereocilia. Semin Cell Dev Biol 19:502-510. CrossRef Medline

Meyers JR, MacDonald RB, Duggan A, Lenzi D, Standaert DG, Corwin JT, Corey DP (2003) Lighting up the senses: FM1-43 loading of sensory cells through nonselective ion channels. J Neurosci 23:4054-4065. Medline

Müller CB, Enderlein J (2010) Image scanning microscopy. Phys Rev Lett 104:198101. CrossRef Medline

Myers KR, Casanova JE (2008) Regulation of actin cytoskeleton dynamics by Arf-family GTPases. Trends Cell Biol 18:184-192. CrossRef Medline

Naslavsky N, Weigert R, Donaldson JG (2003) Convergence of non-clathrinand clathrin-derived endosomes involves Arf6 inactivation and changes in phosphoinositides. Mol Biol Cell 14:417-431. CrossRef Medline
Nishida Y, Rivolta MN, Holley MC (1998) Timed markers for the differentiation of the cuticular plate and stereocilia in hair cells from the mouse inner ear. J Comp Neurol 395:18-28. CrossRef Medline

Osmani N, Peglion F, Chavrier P, Etienne-Manneville S (2010) Cdc42 localization and cell polarity depend on membrane traffic. J Cell Biol 191: 1261-1269. CrossRef Medline

Peng AW, Gnanasambandam R, Sachs F, Ricci AJ (2016) Adaptation independent modulation of auditory hair cell mechanotransduction channel open probability implicates a role for the lipid bilayer. J Neurosci 36: 2945-2956. CrossRef Medline

Plubell DL, Wilmarth PA, Zhao Y, Fenton AM, Minnier J, Reddy AP, Klimek J, Yang X, David LL, Pamir N (2017) Extended multiplexing of tandem mass tags (TMT) labeling reveals age and high fat diet specific proteome changes in mouse epididymal adipose tissue. Mol Cell Proteomics 16: 873-890. CrossRef Medline

Powers RJ, Roy S, Atilgan E, Brownell WE, Sun SX, Gillespie PG, Spector AA (2012) Stereocilia membrane deformation: implications for the gating spring and mechanotransduction channel. Biophys J 102:201-210. CrossRef Medline

Powers RJ, Kulason S, Atilgan E, Brownell WE, Sun SX, Barr-Gillespie PG, Spector AA (2014) The local forces acting on the mechanotransduction channel in hair cell stereocilia. Biophys J 106:2519-2528. CrossRef Medline

Prost J, Barbetta C, Joanny JF (2007) Dynamical control of the shape and size of stereocilia and microvilli. Biophys J 93:1124-1133. CrossRef Medline

Radhakrishna H, Donaldson JG (1997) ADP-ribosylation factor 6 regulates a novel plasma membrane recycling pathway. J Cell Biol 139:49-61. CrossRef Medline

Radhakrishna H, Al-Awar O, Khachikian Z, Donaldson JG (1999) ARF6 requirement for Rac ruffling suggests a role for membrane trafficking in cortical actin rearrangements. J Cell Sci 112:855-866. Medline

Reviriego-Mendoza MM, Santy LC (2015) The cytohesin guanosine exchange factors (GEFs) are required to promote HGF-mediated renal recovery after acute kidney injury (AKI) in mice. Physiol Rep 3:e12442. CrossRef Medline

Roth S, Sheppard CJ, Heintzmann R (2016) Superconcentration of light: circumventing the classical limit to achievable irradiance. Opt Lett 41 : 2109-2112. CrossRef Medline

Sakaguchi H, Tokita J, Naoz M, Bowen-Pope D, Gov NS, Kachar B (2008) Dynamic compartmentalization of protein tyrosine phosphatase receptor Q at the proximal end of stereocilia: implication of myosin VI-based transport. Cell Motil Cytoskeleton 65:528-538. CrossRef Medline

Scheffer, DI, Shen, J, Corey, DP, Chen, ZY (2015) Gene expression by mouse inner ear hair cells during development. J. Neurosci., 35:6366-6380. CrossRef

Schwartz MA, Meredith JE, Kiosses WB (1998) An activated Rac mutant functions as a dominant negative for membrane ruffling. Oncogene 17: 625-629. CrossRef Medline

Seki Y, Miyasaka Y, Suzuki S, Wada K, Yasuda SP, Matsuoka K, Ohshiba Y, Endo K, Ishii R, Shitara H, Kitajiri SI, Nakagata N, Takebayashi H, Kikkawa Y (2017) A novel splice site mutation of myosin VI in mice leads to stereociliary fusion caused by disruption of actin networks in the apical region of inner ear hair cells. PLoS One 12:e0183477. CrossRef Medline

Self T, Sobe T, Copeland NG, Jenkins NA, Avraham KB, Steel KP (1999) Role of myosin VI in the differentiation of cochlear hair cells. Dev Biol 214:331-341. CrossRef Medline

Shen J, Scheffer DI, Kwan KY, Corey DP (2015) SHIELD: an integrative gene expression database for inner ear research. Database 2015:bav071. CrossRef Medline

Sheppard CJ, Mehta SB, Heintzmann R (2013) Superresolution by image scanning microscopy using pixel reassignment. Opt Lett 38:2889-2892. CrossRef Medline

Shi X, Gillespie PG, Nuttall AL (2005) Na+ influx triggers bleb formation on inner hair cells. Am J Physiol Cell Physiol 288:C1332-1341. CrossRef Medline

Shin JB, Krey JF, Hassan A, Metlagel Z, Tauscher AN, Pagana JM, Sherman NE, Jeffery ED, Spinelli KJ, Zhao H, Wilmarth PA, Choi D, David LL, Auer M, Barr-Gillespie PG (2013) Molecular architecture of the chick vestibular hair bundle. Nat Neurosci 16:365-374. CrossRef Medline

Shteyn E, Pigati L, Fölsch H (2011) Arf6 regulates AP-1B-dependent sorting in polarized epithelial cells. J Cell Biol 194:873-887. CrossRef Medline 
Spudich G, Chibalina MV, Au JS, Arden SD, Buss F, Kendrick-Jones J (2007) Myosin VI targeting to clathrin-coated structures and dimerization is mediated by binding to disabled-2 and PtdIns(4,5)P2. Nat Cell Biol 9:176-183. CrossRef Medline

Takatsu H, Yoshino K, Toda K, Nakayama K (2002) GGA proteins associate with Golgi membranes through interaction between their GGAH domains and ADP-ribosylation factors. Biochem J 365:369-378. CrossRef Medline

Thompson A, Schäfer J, Kuhn K, Kienle S, Schwarz J, Schmidt G, Neumann T, Johnstone R, Mohammed AK, Hamon C (2003) Tandem mass tags: a novel quantification strategy for comparative analysis of complex protein mixtures by MS/MS. Anal Chem 75:1895-1904. CrossRef Medline

Tilney LG, Tilney MS, DeRosier DJ (1992) Actin filaments, stereocilia, and hair cells: how cells count and measure. Annu Rev Cell Biol 8:257-274. CrossRef Medline

Torii T, Miyamoto Y, Tago K, Sango K, Nakamura K, Sanbe A, Tanoue A, Yamauchi J (2014) Arf6 guanine nucleotide exchange factor cytohesin-2 binds to CCDC120 and is transported along neurites to mediate neurite growth. J Biol Chem 289:33887-33903. CrossRef Medline

Ueyama T, Sakaguchi H, Nakamura T, Goto A, Morioka S, Shimizu A, Nakao K, Hishikawa Y, Ninoyu Y, Kassai H, Suetsugu S, Koji T, Fritzsch B, Yonemura S, Hisa Y, Matsuda M, Aiba A, Saito N (2014) Maintenance of stereocilia and apical junctional complexes by Cdc42 in cochlear hair cells. J Cell Sci 127:2040-2052. CrossRef Medline

Vizcaíno JA, Csordas A, del-Toro N, Dianes JA, Griss J, Lavidas I, Mayer G, Perez-Riverol Y, Reisinger F, Ternent T, Xu QW, Wang R, Hermjakob H (2016) 2016 update of the PRIDE database and its related tools. Nucleic Acids Res 44:D447-456. CrossRef Medline

Zhang Q, Cox D, Tseng CC, Donaldson JG, Greenberg S (1998) A requirement for ARF6 in Fc $\gamma$ receptor-mediated phagocytosis in macrophages. J Biol Chem 273:19977-19981. CrossRef Medline

Zhao H, Williams DE, Shin JB, Brügger B, Gillespie PG (2012) Large membrane domains in hair bundles specify spatially constricted radixin activation. J Neurosci 32:4600-4609. CrossRef Medline 